\title{
Immunolocalization of antioxidant enzymes in high-pressure frozen root and stem nodules of Sesbania rostrata
}

Maria C. Rubio ${ }^{1}$, Manuel Becana ${ }^{1}$, Sumio Kanematsu², Takashi Ushimaru ${ }^{3}$ and Euan K. James $^{4}$

${ }^{1}$ Departamento de Nutrición Vegetal, Estación Experimental de Aula Dei, Consejo Superior de Investigaciones Científicas, 50080 Zaragoza, Spain; ${ }^{2}$ Department of Food Science, MinamiKyushu University, Kirishima 5-1-2, Miyazaki 880-0032, Japan; ${ }^{3}$ Department of Biology, Faculty of Science, Shizuoka University, 836 Ohya, Shizuoka 422-8529, Japan; ${ }^{4}$ College of Life Sciences, University of Dundee, Dundee DD1 5EH, U.K.

*Dedicated to the memory of our dear friend and colleague John Witty (18 November 1944 to 24 February 2009).

Author for correspondence: Euan K. James

Tel: $+44-1382-384741$

Fax: $+44-1382-345893$

Email:e.k.james@dundee.ac.uk

Total word count: 8502

Summary: 224

Introduction: 663

Materials and Methods: 1040

Results: 2164

Discussion: 1687

Conclusions: 295

References: 938

Number of Tables: 1 (supplementary)

Number of Figures: 7 (1 in colour) 


\section{Summary}

- The activities and localizations of superoxide dismutases (SODs) were compared in root and stem nodules of the semi-aquatic legume Sesbania rostrata using gel-activity assays and immunogold labelling, respectively. Nodules were fixed by high-pressure freezing and dehydrated by freeze substitution.

- Stem nodules showed more total and specific SOD activities than root nodules due to the presence of chloroplastic CuZnSOD. Most of the total SOD activity of stem and root nodules was due to 'cytosolic' CuZnSOD, localized in the cytoplasm and chromatin, and to MnSOD in the bacteroids and in the mitochondria of vascular tissue. FeSOD was present in nodule plastids and in leaf chloroplasts and was found to be associated with chromatin.

- Superoxide production was detected histochemically in the vascular bundles and in the infected tissue of stem and root nodules, whereas peroxide accumulation was observed in the cortical cell walls and intercellular spaces, as well as within the infection threads of both nodule types.

- These data suggest a role of CuZnSOD and FeSOD in protecting nuclear DNA from reactive oxygen species and/or in modulating gene activity. The enhanced levels of CuZnSOD, MnSOD and superoxide production in vascular bundle cells are consistent with a role of CuZnSOD and superoxide in the lignification of xylem vessels, but also suggest additional functions in coping with superoxide production by the high respiratory activity of parenchyma cells.

Keywords: antioxidants, chromatin, nitrogen fixation, photosynthesis, reactive oxygen species, Sesbania rostrata, superoxide dismutases, vascular tissue.

New Phytologist (2009) 


\section{Introduction}

Some (semi)tropical legumes, such as those belonging to the genus Sesbania, have the unique ability to form $\mathrm{N}_{2}$-fixing nodules both on the roots and stems (Becker \& George, 1995; James et al., 2001; Den Herder et al., 2006). The mechanisms of stem and root nodulation in these legumes have been studied in detail using as a model the symbiosis between $S$. rostrata and Azorhizobium caulinodans ORS571 (Den Herder et al., 2006). Stem nodules develop by intercellular entry of the bacteria through fissures that are formed because of the protrusion of adventitious roots ("lateral root base invasion"). Root nodules are formed by the same mechanism when the plants are grown in flooded soils, or by intracellular entry of the bacteria via the hairs located near the root tip ("root hair curl invasion") when the plants are grown in aerated, non-aquatic soils (Den Herder et al., 2006). Formation of root nodules by lateral root base invasion involves reactive oxygen species (ROS), ethylene and gibberellins (D’Haeze et al., 2003; Den Herder et al., 2006).

Stem nodules can be formed in the aerial part, above the water level, or on the flooded stem. The aerial and some submerged stem nodules contain chloroplasts in the cortical cells that surround the infected zone (James et al., 1996). These chloroplasts are photosynthetically competent and evolve $\mathrm{O}_{2}$ (James et al., 1998). Despite the $\mathrm{O}_{2}$-sensitivity of nitrogenase, stem nodules have in general higher rates of $\mathrm{N}_{2}$ fixation than root nodules, suggesting that special adaptations exist in stem nodules to deal with the additional burden of $\mathrm{O}_{2}$ and ROS derived therefrom, such as the superoxide radicals and $\mathrm{H}_{2} \mathrm{O}_{2}$. Experiments with $\mathrm{O}_{2}$-specific microelectrodes have shown that, whereas the $\mathrm{O}_{2}$ concentration in the outer cortex increase from $1 \%$ to $23 \%$ upon illumination of nodules, the $\mathrm{O}_{2}$ concentration in the inner cortex and infected zone remain below 0.00025\% (James et al., 1998). These data may reflect the operation of an $\mathrm{O}_{2}$ diffusion barrier and/or of enhanced respiratory activity in the mid-cortex of stem nodules, as has been also proposed for the root nodules of crop legumes (Witty et al., 1986; Dalton et al., 1998).

An important aspect of $\mathrm{O}_{2}$ metabolism in nodules is the production of ROS, which are either potentially damaging or signaling molecules, depending on their concentration and 
chemical composition. For this reason, steady-state ROS concentrations need to be kept under tight control and this is mainly achieved by antioxidant metabolites and enzymes. The latter include three classes of superoxide dismutases (SODs) that catalyze the dismutation of superoxide radicals to $\mathrm{H}_{2} \mathrm{O}_{2}$ but that differ in their metal cofactors and subcellular localizations (for reviews see Bowler et al., 1994; Alscher et al., 2002). Thus, the CuZnSODs are typically localized in the cytosol and chloroplasts, the MnSODs in the mitochondria and peroxisomes, and the FeSODs in the chloroplasts and cytosol (Sevilla et al., 1980; Bridges \& Salin, 1981; Kanematsu \& Asada, 1990). The three classes of SODs are present in nodules (Puppo et al., 1982; Rubio et al., 2007). The $\mathrm{H}_{2} \mathrm{O}_{2}$ produced by SODs and other enzymatic and nonenzymatic reactions that take place in nodules is eliminated by cytosolic ascorbate peroxidase (APXc) and other peroxidases, and by peroxisomal catalase (Dalton et al., 1993; Matamoros et al., 2003). However, there is scant information about ROS and antioxidant defenses in mature nodules of $S$. rostrata. An early study reported the presence of a CuZnSOD in the chloroplasts of stem nodules and of MnSOD and FeSOD in the bacteroids from stem and root nodules, and the authors proposed that SOD and nitrogenase activities are positively correlated (Puppo et al., 1986). We have conducted a detailed immunolocalization study of some important enzymes involved in ROS scavenging in fully developed stem and root nodules of $S$. rostrata. Moreover, the sites of superoxide radical and $\mathrm{H}_{2} \mathrm{O}_{2}$ production have been localized in nodules with histochemical techniques. Our results point out additional functions of SODs in the nuclei of nodule and leaf cells, as well as in the metabolic activity of vascular bundle cells.

\section{Materials and Methods}

\section{Plant material}

Plants of Sesbania rostrata were inoculated with Azorhizobium caulinodans ORS571 and grown in pots in the greenhouse for $30 \mathrm{~d}$ according to James et al. (1996). Stem nodules, root nodules, and leaves were immediately frozen in liquid $\mathrm{N}_{2}$ for later analysis. At the age of harvest, nodules were actively fixing $\mathrm{N}_{2}$ and contained abundant leghemoglobin. 


\section{Total SOD activity and isoform composition}

SODs were extracted at $4^{\circ} \mathrm{C}$ with $50 \mathrm{mM}$ potassium phosphate buffer ( $\mathrm{pH}$ 7.8) containing 0.1 $\mathrm{mM}$ EDTA, $1 \%(\mathrm{w} / \mathrm{v})$ polyvinylpyrrolidone-10 and 0.1\% (v/v) Triton X-100. Total SOD activity was determined spectrophotometrically at $25^{\circ} \mathrm{C}$ by the ferric cytochrome $c$ method (Rubio et al., 2004). One unit of SOD activity was defined as the amount of the enzyme required to inhibit the reduction of ferric cytochrome $c$ by $50 \%$. The SOD isoforms were resolved on $15 \%$ native gels and identified by differential inhibition of SOD activity with 3 $\mathrm{mM} \mathrm{KCN}$ or $5 \mathrm{mM} \mathrm{H}_{2} \mathrm{O}_{2}$, followed by gel staining by the NBT method (Rubio et al., 2004). Specific activities of SOD isoforms were calculated by applying the relative proportions determined by densitometry of native gels using the ImageJ software (National Institutes of Health, Bethesda) to the total SOD activities.

\section{Immunoblot analyses of antioxidant enzymes}

Proteins were extracted from plant material at $4^{\circ} \mathrm{C}$ with $50 \mathrm{mM}$ potassium phosphate buffer ( $\mathrm{pH}$ 7.8) containing $0.1 \%$ Triton X-100 and a complete protease inhibitor cocktail (Roche, Penzberg, Germany), and were quantified by the Bradford microassay (Bio-Rad, Hercules, CA, USA). Proteins were resolved in $12.5 \%$ SDS-gels and transferred onto polyvinylidene fluoride membranes (Pall Corporation-Gelman) using a transfer buffer consisting of $25 \mathrm{mM}$ Tris-HCl (pH 8.3), $192 \mathrm{mM}$ glycine and 20\% methanol. Membranes were stained with Ponceau to verify equal loading of the lanes and the efficiency of the protein transfer.

Immunoblot analyses of SODs and other antioxidant enzymes were performed following standard protocols using rabbit polyclonal antibodies (dilutions used and references are given in parentheses) raised against CuZnSODp and CuZnSODc from spinach (1:3000; Kanematsu \& Asada, 1990), MnSOD from rice (1:1000; Kanazawa et al., 2000), FeSOD from cowpea (1:1000; Moran et al., 2003), APXc from soybean (1:3000; Dalton et al., 1998) and catalase from pumpkin (1:5000; Yamaguchi \& Nishimura, 1984). For all the enzymes, the secondary antibody was a goat anti-rabbit IgG horseradish peroxidase conjugate (SigmaAldrich, St. Louis, MO, USA), which was used at a dilution of 1:20000. Immunoreactive proteins were visualized using a highly-sensitive chemiluminescent reagent for peroxidase detection (SuperSignal West Pico; Pierce, Rockford, IL, USA). 


\section{Immunogold localization of antioxidant enzymes}

Discs ( $1 \mathrm{~mm}$ in diameter) were punched out of leaves and nodule slices (200 $\mu \mathrm{m}$ thickness) of S. rostrata. Both the leaf and nodule discs were then immediately high-pressure frozen (HPF) using an EM-PACT (Leica) according to Studer et al. (2001). Initial samples of HPF nodules were then freeze-substituted using an EM-AFS freeze-substitution unit (Leica) in anhydrous acetone containing $0.1 \%$ glutaraldehyde, $0.2 \% \mathrm{OsO}_{4}$, and $0.25 \%$ uranyl acetate at $-90^{\circ} \mathrm{C}$, $-65^{\circ} \mathrm{C}$ and $-45^{\circ} \mathrm{C}$ over a period of $68.5 \mathrm{~h}$. After replacing the substitution fluid with pure anhydrous acetone, the samples were slowly (over a period of $4 \mathrm{~h}$ ) brought up to room temperature $\left(25^{\circ} \mathrm{C}\right)$ before being infiltrated and embedded within Durcupan epoxy resin (Sigma-Aldrich). Further additional samples were freeze-substituted in the same acetone solution, but omitting $\mathrm{OsO}_{4}$, and these samples were embedded in Lowicryl HM23 resin (Polysciences; Warrington, PA, USA) at $-45^{\circ} \mathrm{C}$ under UV light according to Moran et al. (2003). Ultrathin sections were taken from osmicated, epoxy resin-embedded samples using a Leica Ultracut E microtome. These were collected on copper grids coated in pioloform and carbon before being stained, viewed, and photographed under a JEOL 1200 EX transmission electron microscope according to Rubio et al. (2004). Ultrathin sections from samples without $\mathrm{OsO}_{4}$ and embedded in Lowicryl HM23 were collected on nickel grids coated in pioloform and carbon, and immunogold labelled using the same polyclonal antibodies described previously for immunoblots, as well as an antibody against the iron-protein of nitrogenase (a kind gift of Paul Ludden; Madison, WI, USA), according to James et al. (1996). Sections were first incubated for $1 \mathrm{~h}$ on a blocking/diluting buffer containing 1\% (v/v) Tween 20, 1\% $(\mathrm{w} / \mathrm{v})$ BSA and $1 \%(\mathrm{v} / \mathrm{v})$ normal goat serum (Sigma-Aldrich) in Tris-buffered saline containing $0.5 \mathrm{~g} \mathrm{~L}^{-1}$ polyethylene glycol-20 K and $14 \mathrm{mM}$ sodium azide, then for $1 \mathrm{~h}$ in a 1:50 dilution (in buffer) of the primary antibody. After washing, the grids were incubated in a 1:100 dilution of goat anti-rabbit antibodies conjugated to 15-nm gold particles (GE Healthcare; Little Chalfont, UK) for $30 \mathrm{~min}$. As negative controls, serial sections were immunogold labelled with nonimmune serum (diluted 1:50) substituted for the primary antibodies. The immunogold labelled sections were stained with $2 \%(w / v)$ aqueous uranyl acetate for $10 \mathrm{~min}$ before viewing and photographing. 


\section{Localization of superoxide radical and $\mathrm{H}_{2} \mathrm{O}_{2}$ production}

Superoxide generation in fresh root and stem nodules was detected using a solution of 0.25 $\mathrm{mM}$ NBT (Sigma-Aldrich) and $2 \mathrm{mM}$ sodium $N, N$-diethyldithiocarbamate in $50 \mathrm{mM}$ potassium phosphate buffer (pH 7.8) for 20 min (Ogawa et al., 1996). Superoxide radicals give rise to a blue colouration, owing to the production and precipitation of formazan, in the presence of NBT when CuZnSOD is inhibited by diethyldithiocarbamate. Sections that had been pre-infused with TMP (Acros Organics, Geel, Belgium) were used as an additional negative control. For the in situ detection of $\mathrm{H}_{2} \mathrm{O}_{2}$ in root and stem nodules, the cerium chloride method (Bestwick et al., 1997) was followed with some modifications (Rubio et al., 2004). Briefly, fresh nodule slices were immediately perfused in $10 \mathrm{mM}$ cerium chloride (Sigma-Aldrich) in $50 \mathrm{mM}$ MOPS ( $\mathrm{pH}$ 7.2) for $1 \mathrm{~h}$ prior to fixation in $2.5 \%(\mathrm{v} / \mathrm{v})$ glutaraldehyde in $0.1 \mathrm{M}$ sodium cacodylate. Nodules with and without cerium chloride were post-fixed for $1 \mathrm{~h}$ in $1 \%(\mathrm{w} / \mathrm{v}) \mathrm{OsO}_{4}$ in $0.1 \mathrm{M}$ cacodylate, dehydrated in an ethanol series at room temperature, and finally embedded in Agar 100 epoxy resin (Agar Aids) at $55^{\circ} \mathrm{C}$ for 48 h. Ultrathin sections were stained with lead citrate for $5 \mathrm{~min}$, followed by $2 \%$ aqueous uranyl acetate for $10 \mathrm{~min}$, and $\mathrm{H}_{2} \mathrm{O}_{2}$ was localized as electron-dense precipitates of cerium perhydroxides (Bestwick et al., 1997). Nodule slices treated with catalase prior to perfusion with cerium chloride were used as negative controls (Rubio et al., 2004).

\section{Results}

Total SOD activity and isoform composition in nodules and leaves of S. rostrata

The first aim of this work was to compare the isoform composition and activities of SODs in root and stem nodules of S. rostrata (Fig. 1). Leaf extracts were also included in this part of the study to confirm the identity of the isoforms. The total SOD activities [units per gram of fresh weight $(\mathrm{FW})]$ and the specific SOD activities (units per milligram of protein) of root nodules, stem nodules and leaves were in the range of those reported for other legumes (Rubio et al., 2004). However, the SOD activity in leaves was significantly greater than in nodules when expressed on a FW basis but lower when expressed as specific activity (Fig. 1a). 
Gel activity staining, in the absence or presence of the inhibitors $\mathrm{KCN}$ and $\mathrm{H}_{2} \mathrm{O}_{2}$, was used to individualize and identify the SOD isoforms in the extracts (Fig. 1b). Root nodules, stem nodules and leaves contained the three classes of SODs, but there were tissue-dependent differences in the levels of the corresponding activities and proteins. In root and stem nodules, the major activity bands corresponded to mitochondrial MnSOD (upper MnSOD band), cytosolic CuZnSOD (CuZnSODc) and bacteroid MnSOD (lower MnSOD band). A faint band of plastidic CuZnSOD (CuZnSODp) was also detectable in stem nodules but not in root nodules. In the leaf extracts, in addition to the two major activity bands of mitochondrial MnSOD and CuZnSODc, there was an intense band of CuZnSODp activity and a faint band of FeSOD activity, which could not be detected in nodules. The lower MnSOD activity band was absent, further confirming its bacterial origin. The activities of each SOD isoform in root nodules, stem nodules and leaves were also determined by scanning the activity gels for each individual extract and then applying the resulting proportions of the isoforms to the total SOD activity determined in the same extract (Fig. 1c). This analysis showed that, in terms of specific activity, the leaves have lower mitochondrial MnSOD activity and greater CuZnSODp activity, whereas the stem and root nodules have greater CuZnSODc activity.

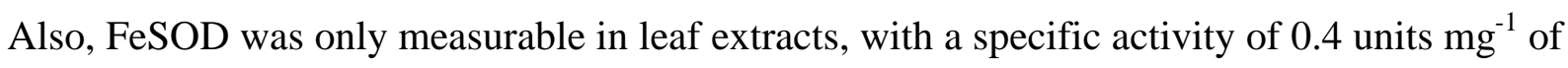
protein, which accounts for approximately $2.5 \%$ of the total SOD activity in the leaves (Fig. 1c).

\section{Immunoblot analyses of SODs and other antioxidant enzymes of nodules}

The second aim of this work was to investigate the localization of antioxidant enzymes in root and stem nodules at the organelle, cell, and tissue levels by electron microscopy. As a prerequisite, immunoblot analyses were performed for the SOD isoforms (Fig. 2a) using polyclonal antibodies raised against the CuZnSODc and CuZnSODp of spinach (Spinacia oleracea), MnSOD of rice (Oryza sativa) and FeSOD of cowpea (Vigna unguiculata). The CuZnSODc antibody recognized a single immunoreactive band of $19 \mathrm{kDa}$ in the two types of nodule extracts, whereas the CuZnSODp antibody recognized a protein of $23 \mathrm{kDa}$ and also a lower immunoreactive band of $19 \mathrm{kDa}$ in both types of nodules. These observations, together 
with the information provided by controls using leaf extracts (which exhibit an intense signal for CuZnSODp) and by immunoblots of native gels similar to that of Figure $1 \mathrm{~b}$ (which allows a clear separation of the two CuZnSOD isoforms), indicate that the CuZnSODp antibody is not absolutely isoform-specific and that the immunoreactive bands of 19 and $23 \mathrm{kDa}$ correspond to the CuZnSODc and CuZnSODp proteins, respectively. The signal intensity of the CuZnSODp protein band on the immunoblots correlated with the abundance of chloroplasts or plastids in the three plant organs tested, being highest in leaves (not shown), weaker in stem nodules, and barely detectable in root nodules (Fig. 2a). On the other hand, the MnSOD antibody recognized an immunoreactive protein of $25 \mathrm{kDa}$ in the two types of nodule extracts, which correspond to the bacteroid and mitochondrial MnSODs, as these enzymes cannot be distinguished by the antibody and have similar subunit size (Rubio et al., 2007). Finally, the FeSOD antibody recognized a protein of $27 \mathrm{kDa}$ in root and stem nodules which is similar in size to that reported for nodules of cowpea (Moran et al., 2003) and Lotus japonicus (Rubio et al., 2007). The detection of FeSOD proteins in immunoblots of nodule extracts but not in the corresponding enzyme activity assays (Fig. 1c) can be attributed to intrinsic differences in the sensitivity of both methods.

Other important enzymes involved in $\mathrm{H}_{2} \mathrm{O}_{2}$ scavenging in plants were examined on immunoblots of nodule extracts (Fig. 2b) as a previous step to immunolocalization studies. In both root and stem nodules, the antibodies raised against APXc of soybean (Glycine max) and catalase of pumpkin (Cucurbita sp.) recognize single immunoreactive protein bands with corresponding apparent molecular masses of 32 and $54 \mathrm{kDa}$, as predicted (Yamaguchi \& Nishimura, 1984; Dalton et al., 1993).

\section{Immunogold localization of antioxidant enzymes in nodules}

Initial attempts to immunogold label SODs in root and stem nodule samples that had been chemically fixed and embedded in LR White resin according to James et al. (1996) were unsuccessful, most likely because the antigens were either removed during the dehydration process prior to the resin infiltration, or else they were damaged by the drastic effects of the 
glutaraldehyde fixation and/or the resin-embedding procedures (Studer et al., 1992; 2001). Therefore, in order to overcome these problems, fresh, unfixed root and stem nodule samples were subjected to high-pressure freezing (HPF), dehydrated by freeze substitution at $-90^{\circ} \mathrm{C}$, and embedded in low temperature resin at $-45^{\circ} \mathrm{C}$. In the first instance, however, it was necessary to check that nodules prepared in this way retained the typical ultrastructure of $S$. rostrata stem and root nodules. For this purpose, high-pressure frozen samples that had been subsequently embedded in an epoxy resin according to Studer et al. (1992) were examined and compared to high-pressure frozen nodules embedded in the low-temperature Lowicryl HM23 resin (Fig. 3). A close examination of the epoxy resin-embedded samples revealed that unfixed, high-pressure frozen A. caulinodans bacteroids in root (Fig. 3a) and stem (Fig. 3b) nodules were similar to those shown in earlier studies using chemical fixation (Tsien et al., 1983; Duhoux, 1984). A similar result was obtained with $S$. rostrata nodules that had been embedded in Lowicryl HM23 (Fig. 3c,d). The latter samples also showed that the nodules were expressing nitrogenase proteins at the time of harvest (Fig. 3c), and that negative control sections incubated in nonimmune serum had negligible cross-reactions with immunogold particles (Fig. 3d). However, perhaps the most interesting observation was that, regardless of the resin used for embedding the samples, the symbiosome membranes were not closely adpressed against the bacteroids, which differ from previous observations of high-pressure frozen soybean nodules (Studer et al., 1992). Also, it is interesting to note the similarly large amounts of poly- $\beta$-hydroxybutyrate granules (gray inclusions) in the bacteroids of both types of nodules (Fig. 3c,d), which suggests some $\mathrm{O}_{2}$ limitation (Mandon et al., 1998). Indeed, the high content of poly- $\beta$-hydroxybutyrate in free-living and symbiotic A. caulinodans has already been described and there is indirect evidence that the infected zone may be more $\mathrm{O}_{2}$ deficient in S. rostrata nodules than in other legume nodules (Bergersen et al., 1986; James et al., 1998).

The four SOD isoforms examined in this study showed distinct localization patterns in nodules. CuZnSODc was sparsely localized in the cytoplasm of infected cells in both root and stem nodules, and also in the vascular bundle cells (not shown). The nucleate vascular bundle cells include phloem companion cells as well as xylem and phloem parenchyma cells. These 
cannot be easily distinguished in transverse sections but all of them showed similar labelling intensity in the cytoplasm, and will therefore be referred to henceforth as (nucleate) vascular bundle cells. However, the most prominent sites of CuZnSODc localization were, by far (>90\%), the nuclei (Supporting Information Table S1). These included the nuclei of infected cells (Fig. 4a), uninfected interstitial cells (not shown), cortical cells (Fig. 4b) and vascular bundle cells (Fig. 4c). The localization of CuZnSODc was highly specific, with negative control sections showing negligible labelling (Fig. 4d, Table S1). This pattern of localization was also observed for leaf cells (Fig. 4e). In all cells and tissues, the labelling was specifically localized to electron-dense regions in the nuclei, particularly at their peripheries. These regions were probably chromatin, and the labelling usually had a ring-shaped pattern, especially when the chromatin strands were sectioned transversely (eg. Fig. 4e). Nucleoli were not labelled. In the case of the nodule vascular tissue, as the cells are smaller than those in the other nodule tissues (compared to the infected cells and to the highly vacuolate cortical cells; James et al., 1996, 1998), the nuclei occupy a much larger proportion of the cell volume, thus meaning that CuZnSODc is probably more concentrated within them.

CuZnSODp was localized in the chloroplasts of stem nodules (Fig. 4f) and leaves, and, albeit at a much lower level, in the plastids of root nodules (not shown). Labelling of MnSOD was observed on the bacteroids (Fig. 5a), but was not generally seen on mitochondria, except on those within the vascular parenchyma (Fig. 5b). Labelling with the FeSOD antibody was found on the chloroplasts of leaves and stem nodules (Fig. 5c), on the plastids of root nodules and on the cytoplasm (not shown) and nuclei of cells of all three plant organs examined. Within the nuclei, FeSOD labelling was found to be closely associated to chromatin (Fig. 5d), as occurred for CuZnSODc, but at lower levels. Consistent with the immunoblot data (Fig. 2), there were no obvious differences between stem and root nodules in either the localization or expression level of APXc and catalase. APXc was localized in the cytoplasm of infected cells surrounding the bacteroids (Fig. 5e), but the protein was also detected within the cortical cells and vascular bundle cells, although at a reduced level compared to the infected cells. Catalase localization was confined to the peroxisomes of infected and uninfected cells in both nodule types (Fig. 5f). 


\section{In situ detection of ROS production}

The substrate (superoxide) and product $\left(\mathrm{H}_{2} \mathrm{O}_{2}\right)$ of SODs were localized using optical and electron microscopy, respectively. The detection of superoxide radical production was based on the superoxide-dependent reduction of nitroblue tetrazolium (NBT) to formazan, which precipitates in tissues. Formation of purple-coloured spots of formazan, marking sites of superoxide production, was observed in fresh sections of stem (Fig. 6a) and root (Fig. 6b,c) nodules infiltrated with NBT and diethyldithiocarbamate, an inhibitor of CuZnSOD (Ogawa et al., 1996). Similar results were obtained when sections were infiltrated with NBT and sodium azide as an inhibitor of CuZnSOD (E.K. James, unpublished). As an additional control, some root nodule sections (Fig. 6d) were incubated with 2,2,6,6tetramethylpiperidinooxy (TMP), a scavenger of superoxide radicals (Romero-Puertas et al., 2004). This control treatment was also useful to distinguish NBT reduction by superoxide radicals and by respiratory dehydrogenases, which are often studied with this procedure (Dalton et al., 1998). The production of superoxide was particularly concentrated within the vascular tissue, as evidenced by deposition of formazan in the vascular bundles in the cortices in both nodule types (Fig. 6a,b), and also by its deposition in the vascular traces entering nodules from the subtending root (Fig. 6c) or stem. Some staining was also observed in the infected zone (Fig. 6a-c), but it was not as reliable because the infected zone contains abundant leghemoglobin, which can produce, or react with, superoxide radicals (Puppo et al., 1982). In fact, control sections pretreated with TMP still show some dark-blue staining in the infected zone (Fig. 6d).

Production of $\mathrm{H}_{2} \mathrm{O}_{2}$ was detected in nodules with a cytochemical technique based on the oxidation of this ROS by cerium chloride to form cerium perhydroxides, which form dense precipitates (Bestwick et al., 1997). Root and stem nodule samples were perfused with cerium chloride and then chemically fixed and prepared for electron microscopy. Sections of mature $\mathrm{N}_{2}$-fixing root and stem nodules prepared in this way had electron dense precipitates of cerium perhydroxide within the cell walls of the remaining infection threads in the invasion 
zone as well as in nearby intercellular spaces (Fig. 7a). Thus, $\mathrm{H}_{2} \mathrm{O}_{2}$ was associated with the infection threads of developing nodules, and also with some of those within mature nodules (Fig. 7b), although most of the infection threads in the latter did not have $\mathrm{H}_{2} \mathrm{O}_{2}$ associated with them (Fig. 7c). $\mathrm{H}_{2} \mathrm{O}_{2}$ was also localized in the apoplast (cell walls and intercellular spaces) of the inner cortex and infected tissue of both types of nodules (Fig. 7a,b), but it was particularly observed within the walls of stem nodule cortical cells that contained chloroplasts (Fig. 7d), and somewhat less so within the walls of root nodule cortical cells. It was not commonly observed within the vascular tissue (Fig. 7e), except occasionally as a very slight precipitation of cerium perhydroxides on the lignified secondary thickening of the xylem vessels. Sections of nodules that had been perfused with catalase prior to the cerium chloride treatment showed no precipitation of cerium perhydroxides (Fig. 7f).

\section{Discussion}

The root and stem nodules used in this study were harvested at the approximate age for which nitrogenase and SOD activities are maximal (Puppo et al., 1986). We found that the SOD specific activities in both nodule types are similar (35-40 units $\mathrm{mg}^{-1}$ protein) and twice as much as the corresponding activity in leaves. However, the total activities in nodules expressed per gram of FW were only $50-70 \%$ of the activity in leaves due to the greater content of total protein in the leaves (c. $60 \mathrm{mg}$ protein per $\mathrm{g} \mathrm{FW}$ ) compared to nodules (c. 20 mg protein per g FW). The specific activities of CuZnSODc and MnSOD isoforms were similar in both nodule types, whereas CuZnSODp activity was detectable only in stem nodules and FeSOD activity only in leaves. The CuZnSODp isoform is probably responsible for the higher total SOD activity per FW found in stem nodules. In fact, CuZnSODp was localized in the stem nodule chloroplasts but also, less expectedly, in the root nodule plastids. This finding explains the faint immunoreactive protein band detected in root nodule extracts on western blots and suggests that CuZnSODp plays an additional role in nonphotosynthetic tissues. In stem nodules, CuZnSODp is involved in the dismutation of superoxide radicals 
generated in the cortical chloroplasts through the Mehler reaction in photosystem I. The substrate for this reaction, molecular $\mathrm{O}_{2}$, would be supplied at high concentrations by photosystem II (James et al., 1998).

In terms of specific activity, CuZnSODc accounted for $50-60 \%$ of the total SOD activity in root nodules, stem nodules and leaves. An important finding of our study is the abundance of CuZnSODc (>90\% of total labelling) in the nuclei of infected and uninfected cells of root and stem nodules, as well as in the cytoplasm of infected and vascular bundle cells. Ogawa et al. (1996) reported that, in spinach leaf cells, the so-called 'cytosolic' CuZnSOD is localized not only in the cytosol but also in the apoplast and nuclei. In our study, the HPF technique allowed for a much more definitive localization of this enzyme on the chromatin of leaf and nodule (infected and uninfected) cells. This suggests that CuZnSODc has the same functions in the nuclei of cells from leaves, root nodules and stem nodules. However, in contrast to the highly oxidizing hydroxyl radicals, superoxide or $\mathrm{H}_{2} \mathrm{O}_{2}$ are not sufficiently reactive on their own to cause damage to DNA or proteins (Halliwell \& Gutteridge, 2007), and hence CuZnSODc may be protecting the nuclei by preventing formation of hydroxyl radicals through Fenton reactions, and/or the enzyme may have additional functions. Virtually nothing is known about ROS production in the nuclei of plant cells, although it has been recently shown that isolated nuclei of tobacco (Nicotiana tabacum) suspension cells can generate $\mathrm{H}_{2} \mathrm{O}_{2}$ in response to calcium addition (Ashtamker et al., 2007). The finding of CuZnSODc and FeSOD, but not MnSOD, in nuclei is strong indirect evidence that ROS are generated under physiological conditions and suggests specific roles for the SOD isoforms in the nuclei. Conceivably, SOD activity in nuclei could modulate the levels of superoxide and $\mathrm{H}_{2} \mathrm{O}_{2}$, and these ROS may affect redox-sensitive transcription factors (Laloi et al., 2004). This hypothesis is supported by the finding of a peroxiredoxin (PER1) in the nuclei of barley embryo and aleurone cells (Stacy et al., 1999). Peroxiredoxins use $\mathrm{H}_{2} \mathrm{O}_{2}$ or other peroxides as substrates and have antioxidant and regulatory roles (Dietz, 2003).

Previous studies of nodules using the antibody against CuZnSODc have shown that this enzyme is abundant in young and meristematic tissues in nodules of alfalfa (Medicago sativa), pea (Pisum sativum) and L. japonicus, and that it is particularly associated with 
infection threads and meristem cell walls (Rubio et al., 2004; 2007). However, we could not determine if this also holds true for the infection threads of mature $S$. rostrata nodules, as meristem activity and bacterial invasion cease early in the development of these nodules (Den Herder et al., 2006). This objective is certainly worth pursuing in future studies, especially as some of the infection threads that we observed were associated with the generation of $\mathrm{H}_{2} \mathrm{O}_{2}$, in agreement with previous observations in developing nodules of S. rostrata (D’Haeze et al., 2003).

We have immunolocalized FeSOD in the chloroplasts, nonphotosynthetic plastids and cytoplasm, which is consistent with our previous study with L. japonicus nodules (Rubio et al., 2007). However, the FeSOD protein was also detected in close association with chromatin in the three plant organs examined, although it was not so abundant as CuZnSODc. The similar locations of FeSOD and CuZnSODc in the chromatin of nodule cells led us to suggest that the two enzymes play analogous roles but possibly at different stages of nodule development. Thus, in a previous study with L. japonicus (Rubio et al., 2007), we found that the CuZnSODc protein level is greater in the early stages of symbiosis and that FeSOD progressively replaces it with advancing age.

The antibody used in our study to localize MnSOD was raised against the enzyme purified from rice (Kanazawa et al., 2000) but was unable to distinguish between the bacterial and plant isoforms. Thus, we detected MnSOD in the bacteroids and mitochondria from root and stem nodules. The MnSOD activity of bacteroids is essential for the onset of symbiosis (Santos et al., 2000). Moreover, our histochemical study confirms that superoxide radicals are generated in the $\mathrm{N}_{2}$-fixing tissue, probably associated to the respiration of bacteroids, which contain high affinity terminal oxidases coupled to nitrogenase activity (Bergersen et al., 1986). A novel finding of this work is that MnSOD was localized specifically in the mitochondria of the vascular bundle cells. In a previous ultrastructural study of legume nodules using this antibody, we showed that MnSOD is present in the mitochondria of infected and uninfected cells of alfalfa (as well as in bacteroids and bacteria within infection threads), but did not find a preferential location in any particular cell type (Rubio et al., 2004). This suggests that vascular bundle cells in S. rostrata nodules may have particularly 
high rates of respiration and hence of ROS formation.

APXc and catalase are abundant hemoproteins of nodules which catalyze, respectively, the reduction of $\mathrm{H}_{2} \mathrm{O}_{2}$ by ascorbate and the decomposition of $\mathrm{H}_{2} \mathrm{O}_{2}$ to water and $\mathrm{O}_{2}$. APXc was localized in the infected cells of stem and root nodules of S. rostrata, as occurs in soybean and alfalfa nodules (Dalton et al., 1993; 1998), whereas intense labelling for catalase was found in the peroxisomes of infected and uninfected cells in both types of nodules.

Indeed, an important finding of this study is the relatively high concentrations of the antioxidant enzymes CuZnSODc and MnSOD in vascular bundle cells. To our knowledge, the presence of antioxidants in the vascular tissue has been investigated only in two plant systems. First, in spinach leaves and hypocotyls, CuZnSODc was associated with the sites of superoxide and $\mathrm{H}_{2} \mathrm{O}_{2}$ production and of lignin deposition, suggesting that CuZnSODc activity is involved in lignification (Ogawa et al., 1996; 1997). Second, in cucumber (Cucumis sativus) and pumpkin plants, the proteins and/or activities of CuZnSODc, monodehydroascorbate reductase, peroxidase and glutathione reductase were detected in the phloem sap (Alosi et al., 1988; Walz et al., 2002). Our co-localization of CuZnSODc and superoxide production in the vascular bundle cells of root and stem nodules supports a role of this enzyme in lignification. However, because mitochondrial MnSOD, but not FeSOD, is also particularly abundant in the vascular tissue, CuZnSODc and MnSOD may perform additional functions. We propose that the enhanced levels of these two SOD isoforms are related to the high respiratory activity of the vascular bundle cells and that mitochondrial respiration is a source of the superoxide radicals detected histochemically. The elevated respiration rates would be explained by intensive energy consuming processes such as the active transport of ions or metabolites.

Another major site of superoxide formation was the chloroplastic-containing cortex of the stem nodules, as well as in the infected zone. This localization pattern in S. rostrata nodules contrasts with that seen in the indeterminate nodules of alfalfa (Santos et al., 2001; Rubio et al., 2004) or pea (Groten et al., 2005), in which ROS were found to be generated in the meristem and invasion zone. The mature nodules of $S$. rostrata lack an active meristem and invasion zone (Fernández-López et al., 1998; Den Herder et al., 2006) and hence we were 
unable to confirm that superoxide and SOD expression are associated with meristematic activity and bacterial invasion in this species. However, the localization of $\mathrm{H}_{2} \mathrm{O}_{2}$ within and close to infection threads reported by D'Haeze et al. (2003) and in the remnants of infection threads found in the present study strongly suggests this possibility.

Finally, it is also important to note that this is the first time that the HPF technique has been used to study $S$. rostrata nodules. Our results show that the structure of nodules processed by $\mathrm{HPF}$, treated with $\mathrm{OsO}_{4}$, and embedded in conventional epoxy resin is similar to that of nodules prepared by conventional chemical fixation (Tsien et al., 1983, Duhoux, 1984). In sharp contrast, in nodules of soybean, lupin (Lupinus albus) or common bean (Phaseolus vulgaris) prepared by HPF, the symbiosome membranes are tightly wrapped around the bacteroids (Studer et al., 1992; de Felipe et al., 1997), whereas in chemically fixed nodules the bacteroids are separated from the symbiosome membrane by a substantial "gap" (eg. Dalton et al., 1993). In the case of soybean nodules, Studer et al. (1992) suggested that only symbiosomes in unfixed nodules prepared by HPF faithfully reflect their natural state, and that the close wrapping of the bacteroids would allow for their much closer proximity to the leghemoglobin-containing cytoplasm. We conclude that the gap between the bacteroids and the symbiosome membrane seen in our study is a genuine feature of the $S$. rostrata root and stem nodule structure. It is likely that, because the leghemoglobins of S. rostrata have very high affinities for $\mathrm{O}_{2}$ compared to those of soybean (Bergersen et al., 1986), the gap between the bacteroids and the symbiosome membrane may actually be required to prevent nitrogenase from being inactivated by the high $\mathrm{O}_{2}$ flux supplied by $S$. rostrata leghemoglobins.

\section{Conclusions}

This study on the localization of SODs, other antioxidants, and ROS in S. rostrata nodules led us to a number of findings. First, the relatively high SOD activity of stem nodules is due to CuZnSODp, which helps to prevent photosynthetically-generated ROS from damaging the 
$\mathrm{N}_{2}$-fixing cells. Second, by far the greatest proportion of total SOD activity (>60\%) in both nodule types is ascribable to CuZnSODc, and much of this enzyme appears to be associated with chromatin in the nuclei of infected and uninfected host cells and also of leaf cells, suggesting that CuZnSODc in nodules and leaves may be involved in protecting DNA from ROS or in modulating gene activity. Third, high levels of CuZnSODc and mitochondrial MnSOD were found in vascular bundle cells, in agreement with the histochemical localization of superoxide radicals. This is consistent with a role of superoxide and CuZnSODc in the lignification of xylem vessels, but also points out additional functions of these antioxidant enzymes in the vascular bundles, such as the scavenging of the high ROS levels produced during respiration in vascular bundle cells. Finally, superoxide generated within the photosynthetic tissue of stem nodules is scavenged by CuZnSODp in the chloroplasts and by

CuZnSODc in the cytosol and nuclei. Because there was no excess production of $\mathrm{H}_{2} \mathrm{O}_{2}$ in these cells, this ROS may be efficiently removed by APXc and catalase. On the other hand, the accumulation of $\mathrm{H}_{2} \mathrm{O}_{2}$ in the apoplast suggests that some excess $\mathrm{H}_{2} \mathrm{O}_{2}$ is exported (or leaks?) from the cells. This $\mathrm{H}_{2} \mathrm{O}_{2}$ may be involved in the rapid $\mathrm{H}_{2} \mathrm{O}_{2}$-mediated cross-linking of the matrix glycoprotein that is located in the cell walls and intercellular spaces of the photosynthetic cortex of stem nodules and that is probably involved in the operation of the $\mathrm{O}_{2}$ diffusion barrier (James et al., 1996).

\section{Acknowledgements}

We thank Carmen Pérez-Rontomé (CSIC) for technical assistance and Alan Prescott (University of Dundee) for helpful discussions. This work was supported by the Royal Society (U.K.), Ministerio de Educación y Ciencia-Fondos Europeos de Desarrollo Regional (AGL2005-01404 and AGL2008-01298) and Gobierno de Aragón (group A53). Euan K. James thanks the Royal Society (U.K.) and Gobierno de Aragón-Caja Inmaculada (Spain) for funding a sabbatical leave ("Programa Europa”). Maria C.Rubio was the recipient of a postdoctoral contract (Program I3P) of Consejo Superior de Investigaciones CientíficasFondo Social Europeo.

Received February 8, 2009; 


\section{References}

Alosi MC, Melroy DL, Park RB. 1988. The regulation of gelation of phloem exudate from Cucurbita fruit by dilution, glutathione, and glutathione reductase. Plant Physiology 86: 1089-1094.

Alscher RG, Ertuk N, Heath LS. 2002. Role of superoxide dismutases (SODs) in controlling oxidative stress in plants. Journal of Experimental Botany 53: 1331-1341.

Ashtamker C, Kiss V, Sagi M, Davydov O, Fluhr R. 2007. Diverse subcellular locations of crytogein-induced reactive oxygen species production in tobacco bright yellow-2 cells. Plant Physiology 143: 1817-1826.

Becker M, George T. 1995. Nitrogen fixation response of stem- and root-nodulating Sesbania species to flooding and mineral nitrogen. Plant and Soil 175: 189-196.

Bergersen FJ, Turner GL, Bogusz D, Wu YQ, Appleby CA. 1986. Effects of $\mathrm{O}_{2}$ concentrations and various haemoglobins on respiration and nitrogenase activity of bacteroids from stem and root nodules of Sesbania rostrata and of the same bacteria from continuous cultures. Journal of General Microbiology 132: 3325-3336.

Bestwick CS, Brown IR, Bennett MR, Mansfield JW. 1997. Localization of hydrogen peroxide accumulation during the hypersensitive reaction of lettuce cells to Pseudomonas syringae pv. phaseolicola. Plant Cell 9: 209-221.

Bowler C, Van Camp W, Van Montagu M, Inzé D. 1994. Superoxide dismutase in plants. Critical Reviews in Plant Sciences 13: 199-218.

Bridges SM, Salin ML. 1981. Distribution of iron-containing superoxide dismutase in vascular plants. Plant Physiology 68: 275-278.

Dalton DA, Baird LM, Langeberg L, Taugher CY, Anyan WA, Vance CP, Sarath G. 1993. Subcellular localization of oxygen defense enzymes in soybean (Glycine max [L.] Merr.) root nodules. Plant Physiology 102: 481-489.

Dalton DA, Joyner SL, Becana M, Iturbe-Ormaetxe I, Chatfield JM. 1998. Antioxidant defenses in the peripheral cell layers of legume root nodules. Plant Physiology 116: 37-43.

de Felipe MR, Lucas MM, Lechaire JP, Nicolas G, Fernández-Pascual M, Pozuelo JM. 1997. Comparative study of two cryotechniques to elucidate real functional aspects of legume nodules development. Journal of Plant Physiology 150: 428-436.

Den Herder G, Schroeyers K, Holsters M, Goormchtig S. 2006. Signaling and gene expression for water-tolerant legume nodulation. Critical Reviews in Plant Sciences 25: 367-380.

D’Haeze W, De Rycke R, Mathis R, Goormachtig S, Pagnotta S, Verplancke C, Capoen W, Holsters M. 2003. Reactive oxygen species and ethylene play a positive role in lateral root base 
nodulation of a semiaquatic legume. Proceedings of the National Academy of Sciences of USA 100: 11789-11794.

Dietz KJ. 2003. Plant peroxiredoxins. Annual Review of Plant Biology 54: 93-107.

Duhoux E. 1984. Ontogénèse des nodules caulinaires du Sesbania rostrata (légumineuses). Canadian Journal of Botany 62: 982-994.

Fernández-López M, Goormachtig S, Gao M, D’Haeze W, Van Montagu M, Holsters M. 1998. Ethylene-mediated phenotypic plasticity in root nodule development on Sesbania rostrata. Proceedings of the National Academy of Sciences of USA 95: 12724-12728.

Groten K, Vanacker H, Dutilleul C, Bastian F, Bernard S, Carzaniga R, Foyer CH. 2005. The roles of redox processes in pea nodule development and senescence. Plant Cell \& Environment 28: 1293-1304.

Halliwell B, Gutteridge JMC. 2007. Free Radicals in Biology and Medicine, Ed 4. Oxford University Press, Oxford

James EK, Iannetta PPM, Nixon PJ, Whiston AJ, Peat L, Crawford RMM, Sprent JI, Brewin NJ. 1996. Photosystem II and oxygen regulation in Sesbania rostrata stem nodules. Plant Cell \& Environment 19: 895-910.

James EK, Minchin FR, Oxborough K, Cookson A, Baker NR, Witty JF, Crawford RMM, Sprent JI. 1998. Photosynthetic oxygen evolution within Sesbania rostrata stem nodules. Plant Journal 13: 29-38.

James EK, Loureiro MF, Pott A, Pott VJ, Martins CM, Franco AA, Sprent JI. 2001. Floodingtolerant legume symbioses from the Brazilian Pantanal. New Phytologist 150: 723-738.

Kanazawa S, Sano S, Koshiba T, Ushimaru T. 2000. Changes in antioxidative enzymes in cucumber cotyledons during natural senescence: comparison with those during dark-induced senescence. Physiologia Plantarum 109: 211-216.

Kanematsu S, Asada K. 1990. Characteristic amino acid sequences of chloroplast and cytosol isozymes of CuZn-superoxide dismutase in spinach, rice and horsetail. Plant Cell Physiology 31: 99-112.

Laloi C, Apel K, Danon A. 2004. Reactive oxygen signalling: the latest news. Current Opinion in Plant Biology 7: 323-328.

Mandon K, Michel-Reydellet N, Encarnación S, Kaminski PA, Leija A, Cevallos MA, Elmerich C, Mora J. 1998. Poly- $\beta$-hydroxybutyrate turnover in Azorhizobium caulinodans is required for growth and affects nifA expression. J Bacteriol 180: 5070-5076.

Matamoros MA, Dalton DA, Ramos J, Clemente MR, Rubio MC, Becana M. 2003. Biochemistry and molecular biology of antioxidants in the rhizobia-legume symbiosis. Plant Physiology 133: 499-509. 
Moran JF, James EK, Rubio MC, Sarath G, Klucas RV, Becana M. 2003. Functional characterization and expression of a cytosolic iron-superoxide dismutase from cowpea root nodules. Plant Physiology 133: 733-782.

Ogawa K, Kanematsu S, Asada K. 1996. Intra- and extra-cellular localization of “cytosolic” CuZnsuperoxide dismutase in spinach leaf and hypocotyl. Plant Cell Physiology 37: 790-799.

Ogawa K, Kanematsu S, Asada K. 1997. Generation of superoxide anion and localization of CuZnsuperoxide dismutase in the vascular tissue of spinach hypocotyls: their association with lignification. Plant Cell Physiology 38: 1118-1126.

Puppo A, Dimitrijevic L, Rigaud J. 1982. Possible involvement of nodule superoxide dismutase and catalase in leghemoglobin protection. Planta 156: 374-379.

Puppo A, Dimitrijevic L, Trinchant JC, Rigaud J. 1986. Acetylene reduction and superoxide dismutase activities in Sesbania rostrata root and stem nodules. Physiologie Végétale 24: 689-696.

Romero-Puertas MC, Rodríguez-Serrano M, Corpas FJ, Gómez M, del Río LA, Sandalio LM. 2004. Cadmium-induced subcellular accumulation of $\mathrm{O}_{2}$ - and $\mathrm{H}_{2} \mathrm{O}_{2}$ in pea leaves. Plant Cell \& Environment 27: 1122-1134.

Rubio MC, James EK, Clemente MR, Bucciarelli B, Fedorova M, Vance CP, Becana M. 2004. Localization of superoxide dismutases and hydrogen peroxide in legume root nodules. Molecular Plant-Microbe Interactions 17: 1294-1305.

Rubio MC, Becana M, Sato S, James EK, Tabata S, Spaink HP. 2007. Characterization of genomic clones and expression analysis of the three types of superoxide dismutases during nodule development in Lotus japonicus. Molecular Plant-Microbe Interactions 20: 262-275.

Santos R, Hérouart D, Puppo A, Touati D. 2000. Critical protective role of bacterial superoxide dismutase in Rhizobium-legume symbiosis. Molecular Microbiology 38: 750-759.

Santos R, Hérouart D, Sigaud S, Touati D, Puppo A. 2001. Oxidative burst in alfalfaSinorhizobium meliloti symbiotic interaction. Molecular Plant-Microbe Interactions 14: 86-89.

Sevilla F, López-Gorgé J, Gómez M, del Río LA. 1980. Manganese superoxide dismutase from a higher plant. Planta 150: 153-157.

Stacy RAP, Nordeng TW, Culiáñez-Macià FA, Aalen RB. 1999. The dormancy-related peroxiredoxin anti-oxidant, PER1, is localized to the nucleus of barley embryo and aleurone cells. Plant Journal 19: 1-8.

Studer D, Hennecke H, Müller M. 1992. High-pressure freezing of soybean nodules leads to an improved preservation of ultrastructure. Planta 188: 155-163.

Studer D, Graber W, Al-Amoudi A, Eggli P. 2001. A new approach for cryofixation by high pressure freezing. Journal of Microscopy 203: 285-294.

Tsien HC, Dreyfus BL, Schmidt EL. 1983. Initial stages in the morphogenesis of nitrogen-fixing stem nodules of Sesbania rostrata. Journal of Bacteriology 156: 888-897. 
Walz C, Juenger M, Schad M, Kehr J. 2002. Evidence for the presence and activity of a complete antioxidant defence system in mature sieve tubes. Plant Journal 31: 189-197.

Witty JF, Minchin FR, Skøt L, Sheehy JE. 1986. Nitrogen fixation and oxygen in legume root nodules. Oxford Surveys of Plant Molecular and Cell Biology 3: 275-314.

Yamaguchi J, Nishimura M. 1984. Purification of glyoxysomal catalase and immunochemical comparison of glyoxysomal and leaf peroxisomal catalase in germinating pumpkin cotyledons. Plant Physiology 74: 261-267. 


\section{Legends for Figures}

Fig. 1. Total SOD activity and activities of SOD isoforms in root nodules (RN), stem nodules (SN), and leaves (L) of S. rostrata. (a) Total SOD activity expressed in units per gram of FW and in units per milligram of protein. Values are means \pm SE of six replicates from plants grown independently. (b) Identification of SOD isoforms on native gels. The method is based on the reduction of NBT to blue formazan by the superoxide radicals generated photochemically. SOD activity inhibits this reaction and SOD isoforms are visualized as achromatic bands on a blue background. Each lane was loaded with $50 \mu$ g of protein. (c) Activity of mitochondrial MnSOD (MnSODm), bacteroid MnSOD (MnSODb), CuZnSODc, CuZnSODp, and FeSOD. The activity of the FeSOD isoform in leaves was $<3 \%$ of total. Values are means \pm SE of six replicates from plants grown independently.

Fig. 2. Immunoblot analysis of antioxidant enzymes in root nodules (RN) and stem nodules (SN) of S. rostrata. (a) Blot of SOD isoforms. Lanes were loaded with $50 \mu$ g (CuZnSODp and FeSOD) or $60 \mu \mathrm{g}$ (CuZnSODc and MnSOD) of protein. (b) Blot of catalase and APXc. Lanes were loaded with $40 \mu \mathrm{g}$ (catalase) or $50 \mu \mathrm{g}$ (APXc) of protein. Approximate molecular masses $(\mathrm{kDa})$ are indicated on the left.

Fig. 3. Transmission electron micrographs of symbiosomes in S. rostrata root (a) and stem (b-d) nodules that had been high pressure frozen, freeze-substituted and embedded either in epoxy resin at $60^{\circ} \mathrm{C}(\mathrm{a}, \mathrm{b})$ or in Lowicryl $\mathrm{HM} 23$ at $-45^{\circ} \mathrm{C}(\mathrm{c}, \mathrm{d})$. Note that the symbiosome membrane (arrows) is usually not closely adpressed against the bacteroids in any of the micrographs. The samples embedded in Lowicryl HM23 were immunogold labelled either with an antibody against the nitrogenase iron-protein (NifH protein) (large arrow) (c) or with nonimmune serum (d). These demonstrate, respectively, that the bacteroids were actively expressing the enzyme at the time of harvest (30 d after inoculation) and also that there was 
negligible non-specific labelling. Note that bacteroids contain numerous granules of poly$\beta$-hydroxybutyrate (gray inclusions in c,d). b, bacteroid. Bars $=2 \mu \mathrm{m}$ (a), $1 \mu \mathrm{m}$ (b), $500 \mathrm{~nm}$ (c, d).

Fig. 4. Transmission electron micrographs of sections of high-pressure frozen S. rostrata stem nodules (a-d, f) and leaves (e) immunogold labelled with an antibody raised against CuZnSODc (a-c, e), treated with nonimmune serum (d), or immunogold labelled with an antibody raised against CuZnSODp (f). In both root and stem nodules, CuZnSODc was almost exclusively localized (arrows) on electron-dense regions within the nuclei of all cells examined, including infected cells (a), cortical cells (b) and vascular parenchyma cells (c). Little or no labelling was seen in bacteroids, cytoplasm, mitochondria, plastids or vacuoles. Also, labelling was not seen on sections that had been treated with nonimmune serum substituted for the primary antibody, including the electron-dense regions in the nuclei (arrows in d). CuZnSODc was also localized in the nuclei of leaf cells (e), but was not present in chloroplasts. CuZnSODp was localized exclusively in chloroplasts (f) and plastids. b, bacteroid; c, cytoplasm; ch, chloroplast; m, mitochondrion; n, nucleus; p, plastid; v, vacuole. Bars= $500 \mathrm{~nm}(\mathrm{a}, \mathrm{b}, \mathrm{e}), 1 \mu \mathrm{m}$ (c, d, f).

Fig. 5. Transmission electron micrographs of sections of high-pressure frozen S. rostrata stem (a-e) and root (f) nodules immunogold labelled with an antibody raised against MnSOD (a, b), FeSOD (c, d), APXc (e) and catalase (f). MnSOD was localized in bacteroids within infected cells (a) and also in mitochondria of parenchyma and phloem cells in the vascular bundles (b). FeSOD was localized in chloroplasts of stem nodules (c) and in electron-dense regions of nuclei (arrows) of all cell types in both stem (d) and root nodules. Immunolabelling with the APXc antibody was localized in the cytoplasm of infected cells (e), and that with the catalase antibody was found exclusively in peroxisomes (arrows). b, bacteroid; c, cytoplasm; ch, chloroplast; m, mitochondrion; n, nucleus; v, vacuole. Bars=500 $\mathrm{nm}(\mathrm{a}-\mathrm{c}), 1 \mu \mathrm{m}(\mathrm{d}-\mathrm{f})$. 
Fig. 6. Localization of superoxide in freshly-cut sections of stem (a) and root (b-d) nodules after treatment with NBT in the presence of diethyldithiocarbamate. Production of superoxide radicals was marked as purple-colored deposits of formazan in the vascular tissue (arrows) in the photosynthetic, chloroplast-containing cortices of stem nodules (a) and in the nonphotosynthetic cortices of root nodules (b). Formazan was also seen in vascular tissue in the base of nodules where they were connected to the subtending root (c). The deposition of formazan in the vascular tissue was greatly reduced (arrows) in sections that were perfused with TMP prior to treatment with NBT (d). The infected tissue is indicated by an asterisk in each section. ch, chloroplast. Bars $=100 \mu \mathrm{m}$ (a-d).

Fig. 7. Localization of $\mathrm{H}_{2} \mathrm{O}_{2}$ in stem nodules as precipitates of electron-dense cerium perhydroxides after treatment with cerium chloride. Dark staining due to cerium perhydroxides was seen associated with infection threads (large arrows) and nearby cell walls and intercellular spaces (small arrows) in the invasion zone (a). This localization was also occasionally observed within the infected zone (b), but in most cases the remaining infection threads in the infected cells were not stained with cerium (c). Cerium deposits were frequently observed within the cell walls in the cortices of both stem and root nodules; in stem nodules these deposits were often close to chloroplasts (d). Little or no cerium staining was observed in the vascular bundles (e), and no cerium deposits were seen in sections that had been treated with catalase prior to the cerium chloride staining (f). b, bacteroid; ch, chloroplast; cw, cell wall; is, intercellular space; it, infection thread; x, xylem; xp, xylem parenchyma. Bars= $1 \mu \mathrm{m}$ (a-c, e, f), $2 \mu \mathrm{m}(\mathrm{d})$. 


\section{Supporting Information}

Additional supporting information may be found in the online version of this article.

Table S1 Relative abundance of CuZnSODc protein in stem and root nodules of Sesbania rostrata 
Fig. 1

(a)

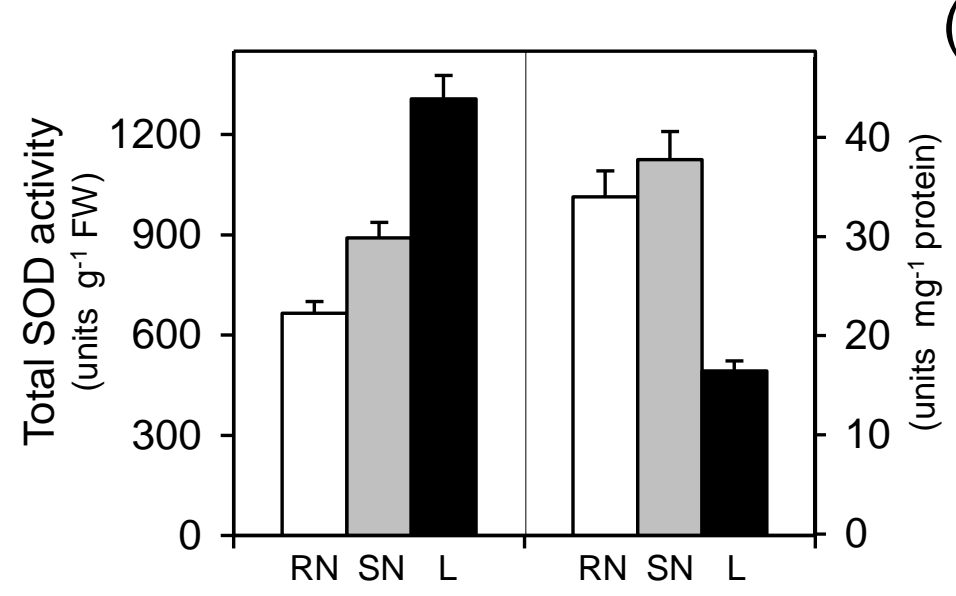

(b)

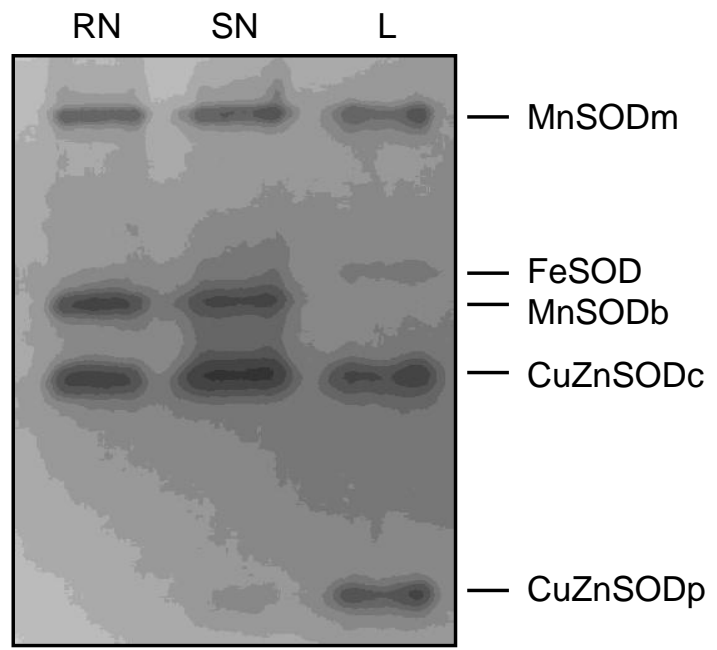

(c)

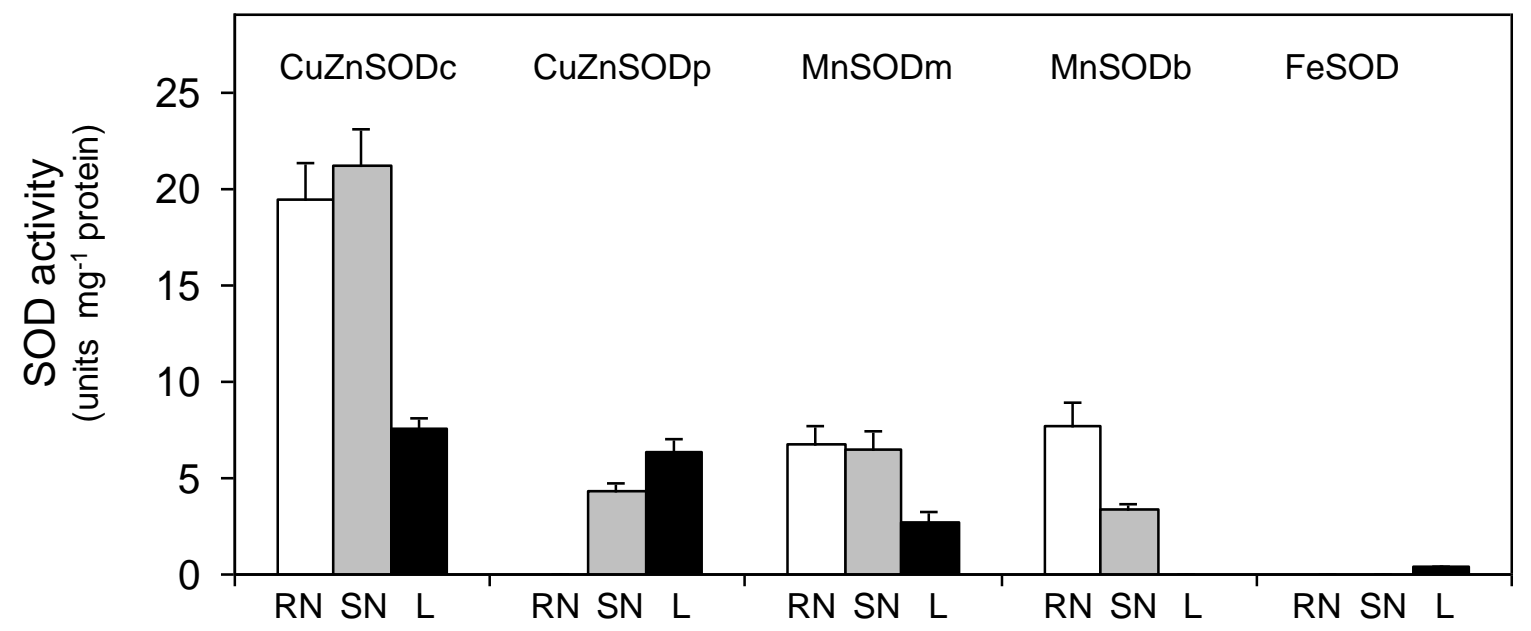


Fig. 2

(a)

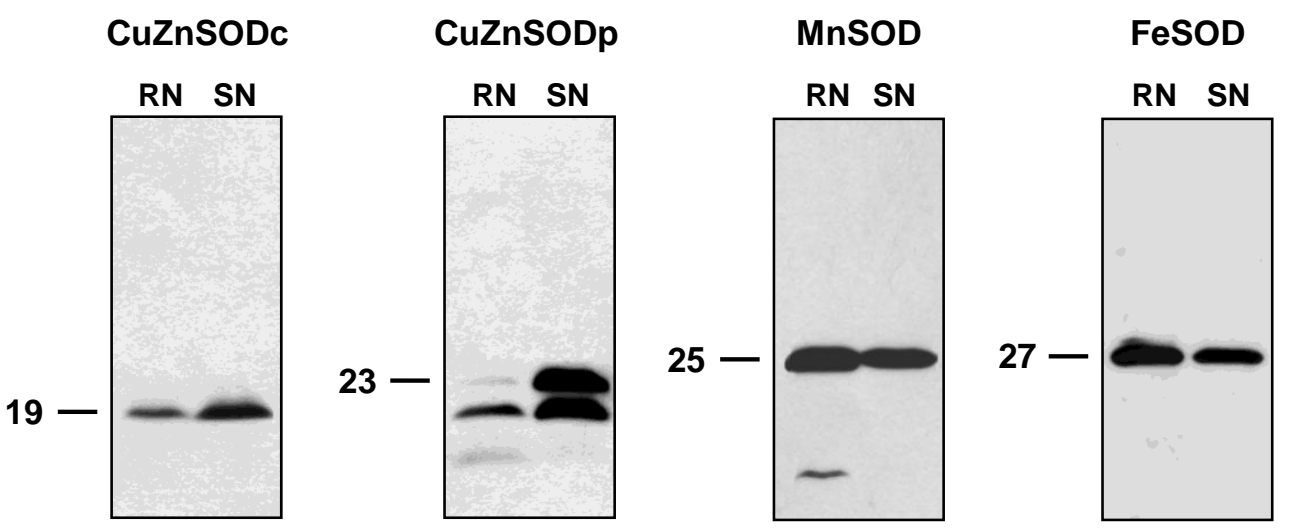

(b)

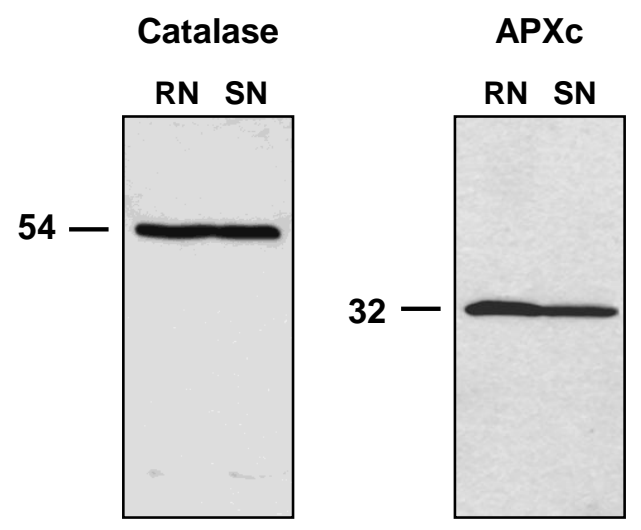


(a) 600.00

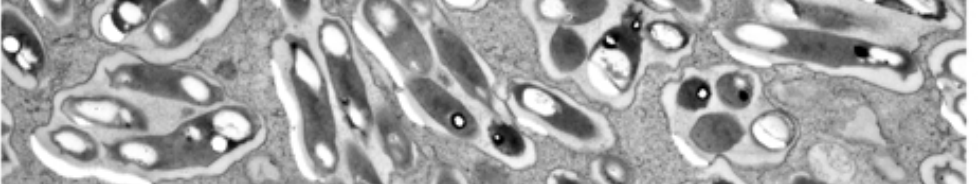

(b) $-00 \% 0$ 0 - 0.68 ( ) - 0 - 1

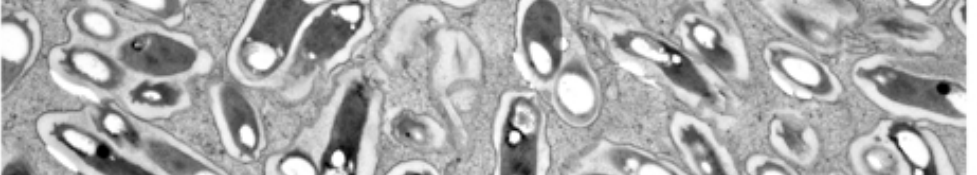
- 1 - 0.8 - 40.91 - $788^{4}$

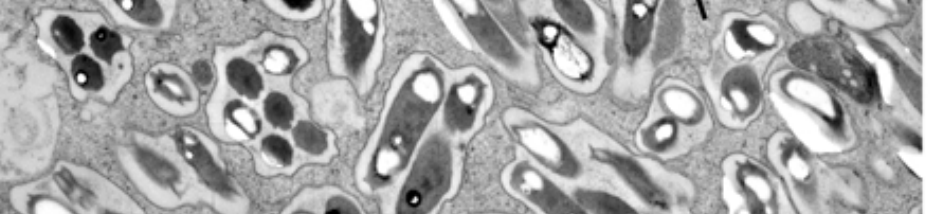
$10^{\circ}+8,40$

(c)

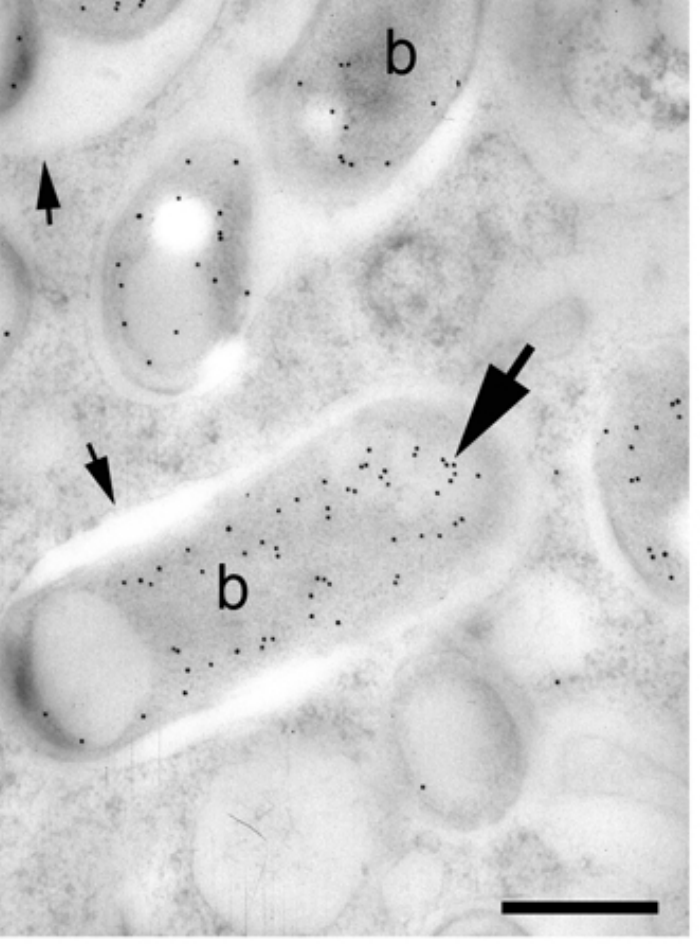

(d)

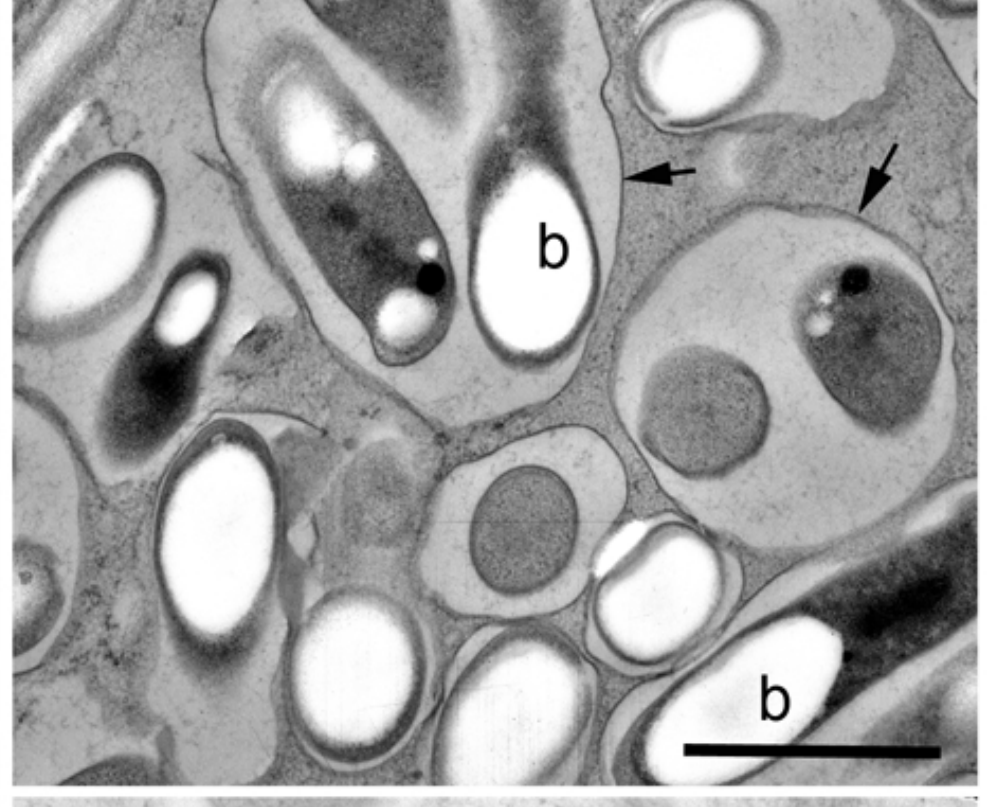

Fig. 3

b

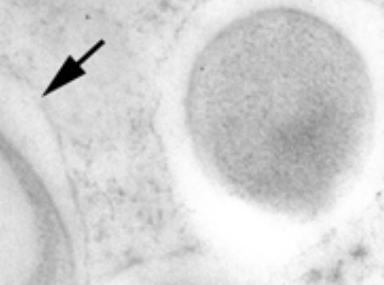

b

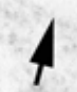

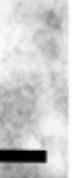


(a)

$x^{2}+t^{2}+\frac{1}{a}$

$+3$

$\rightarrow$

C

m

(c)

b $m+$

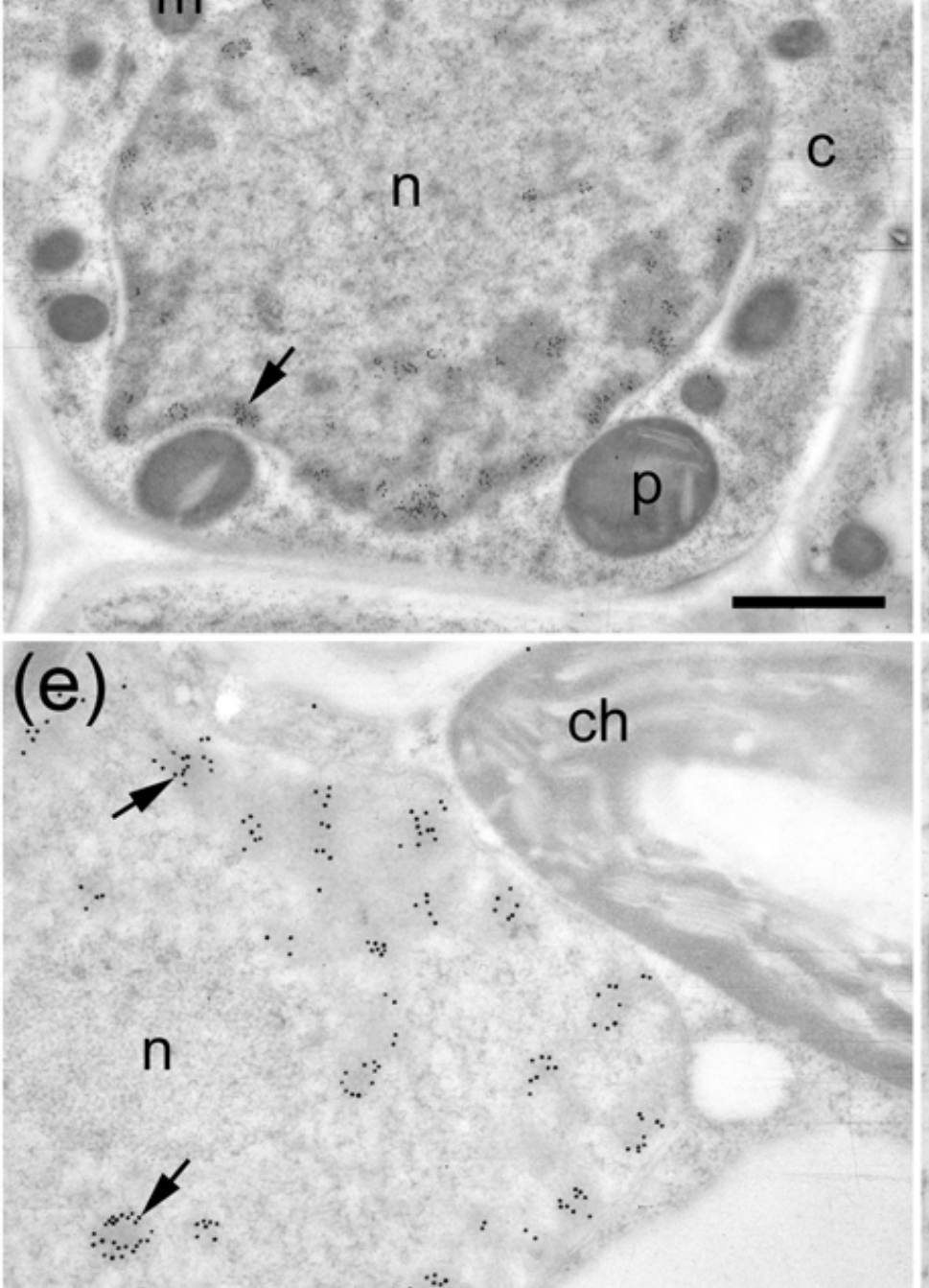

(e)

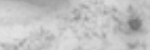

.

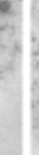

(d)

m

$n$
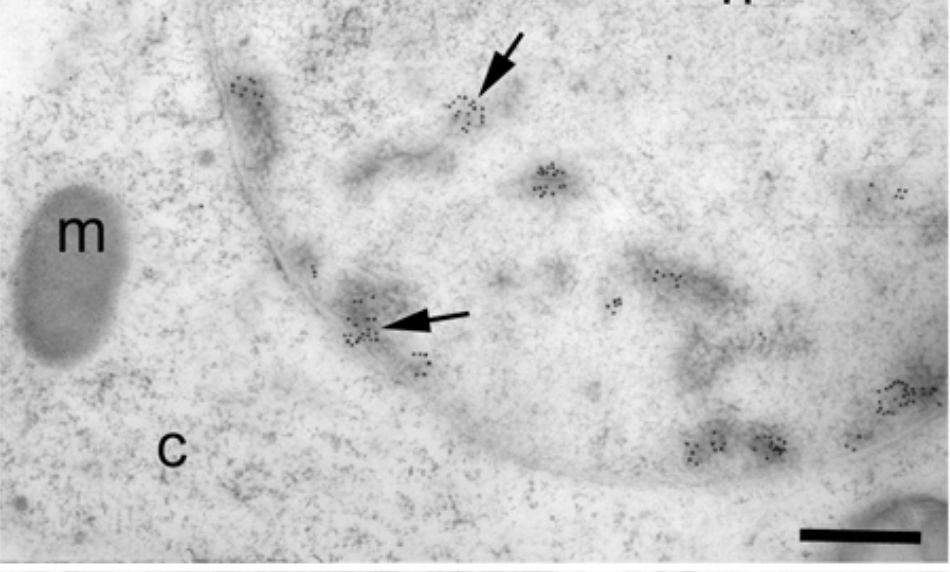

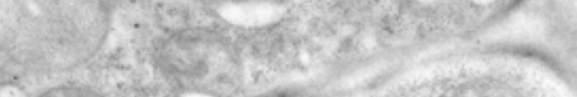

m

C

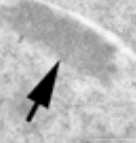

v

(f)

C

Fig. 4

a ch

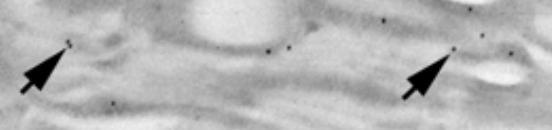

ch 


\section{C}

b

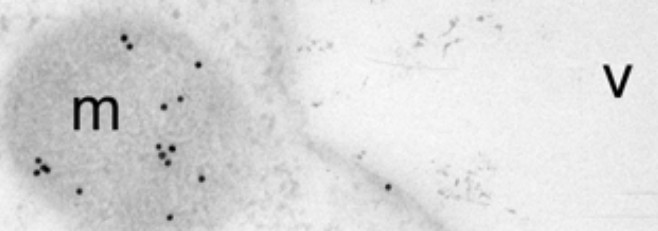

b

(c).

(d)
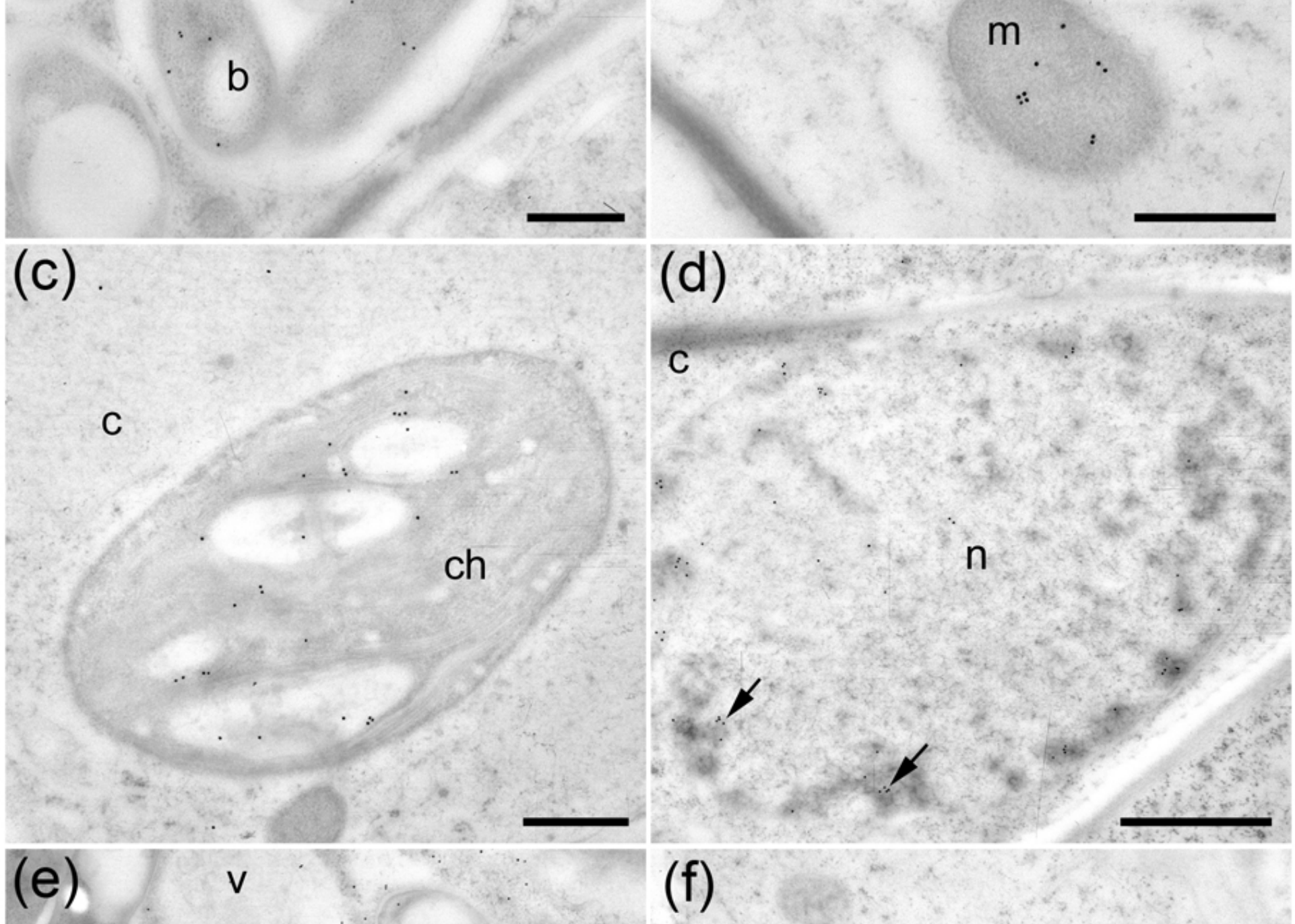

b

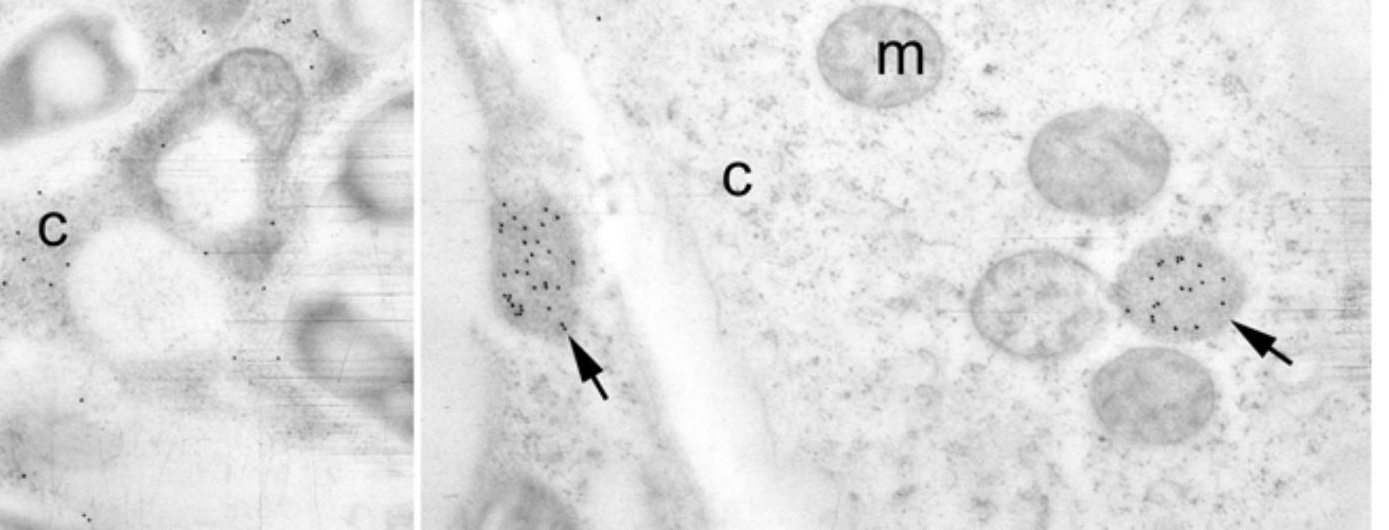

b 
(b)

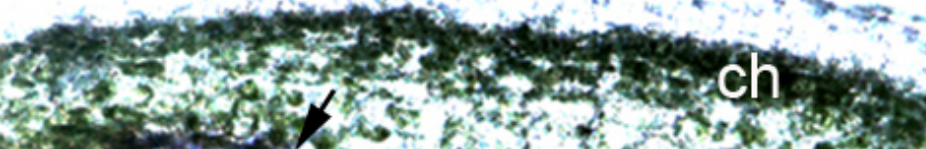
3.

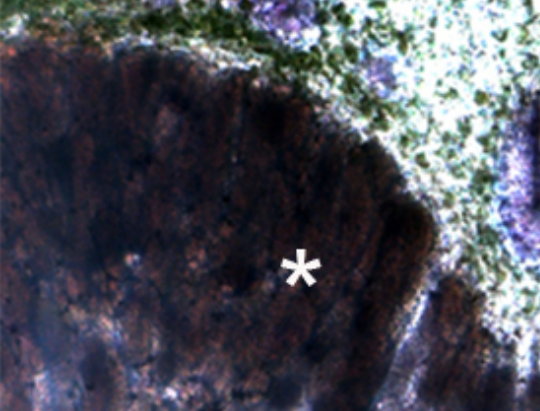

H. $+1 \times$
(c) 5 eese?
-
ho a $=5$

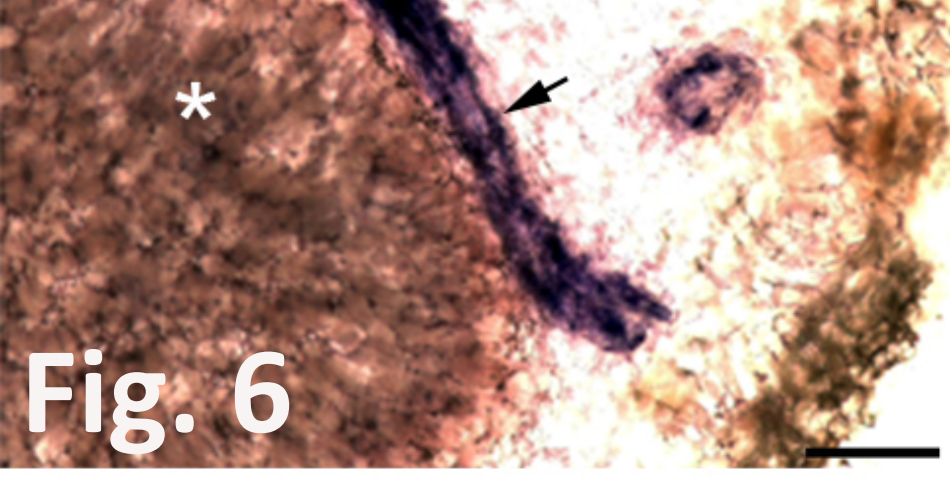

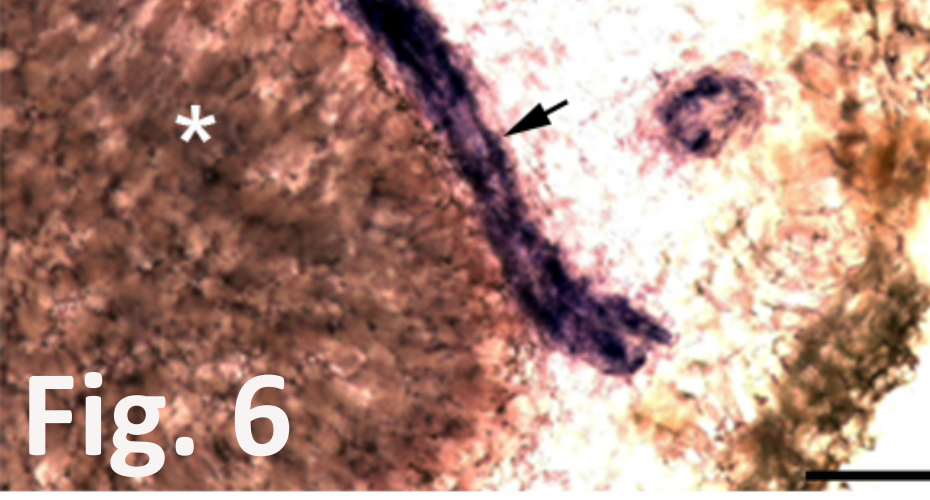
(1)
(1) 2
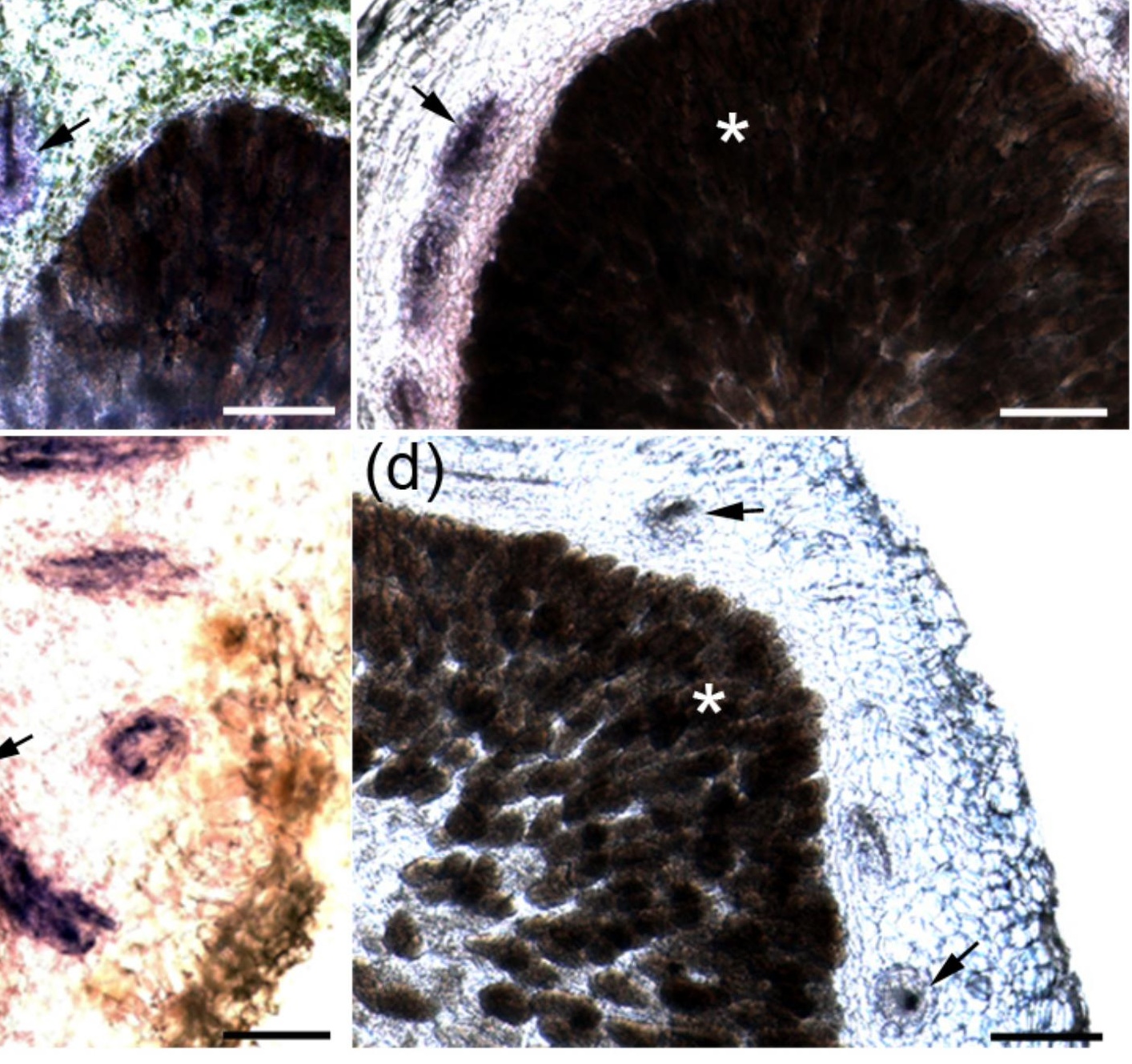

3 side
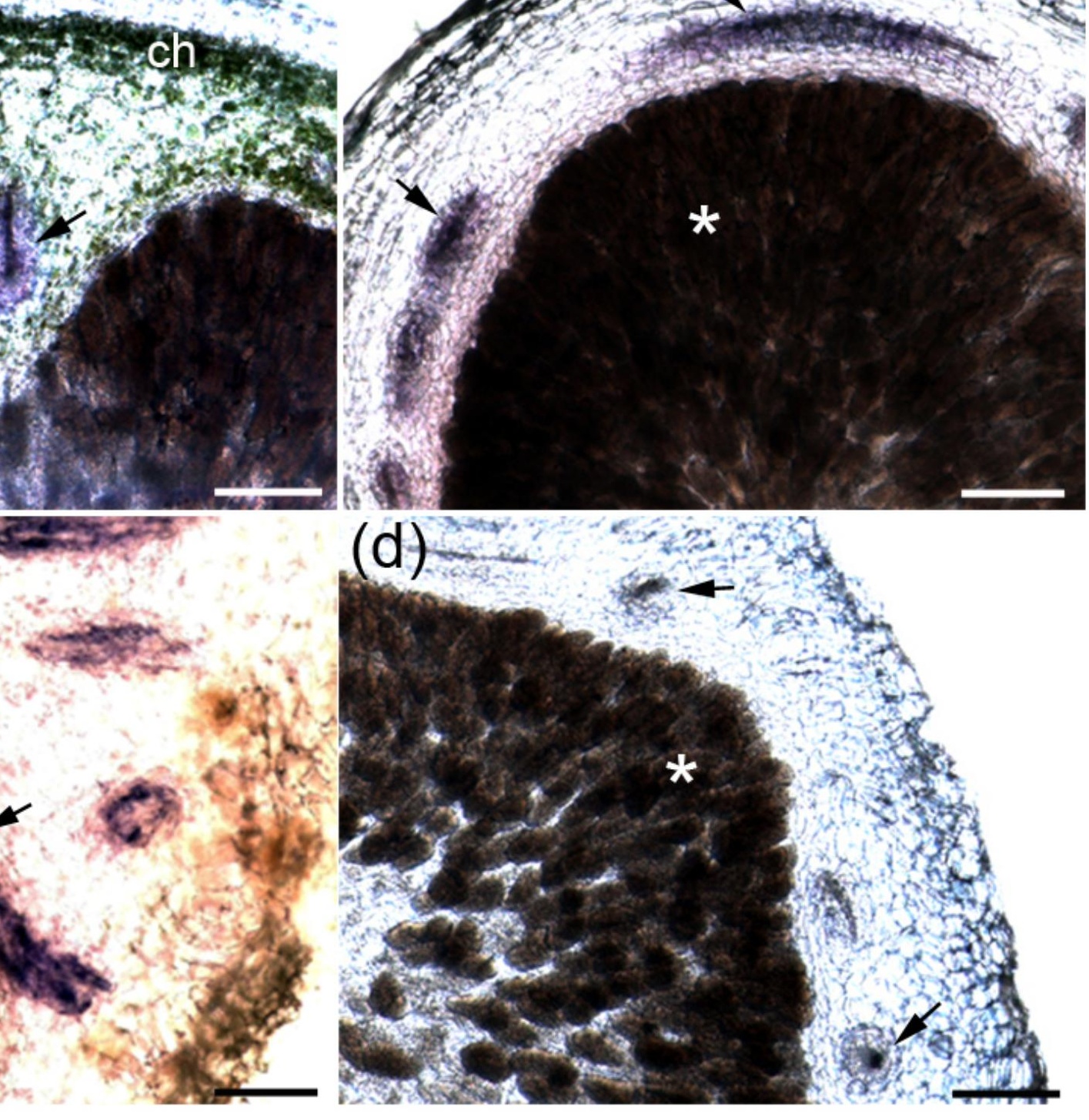

k

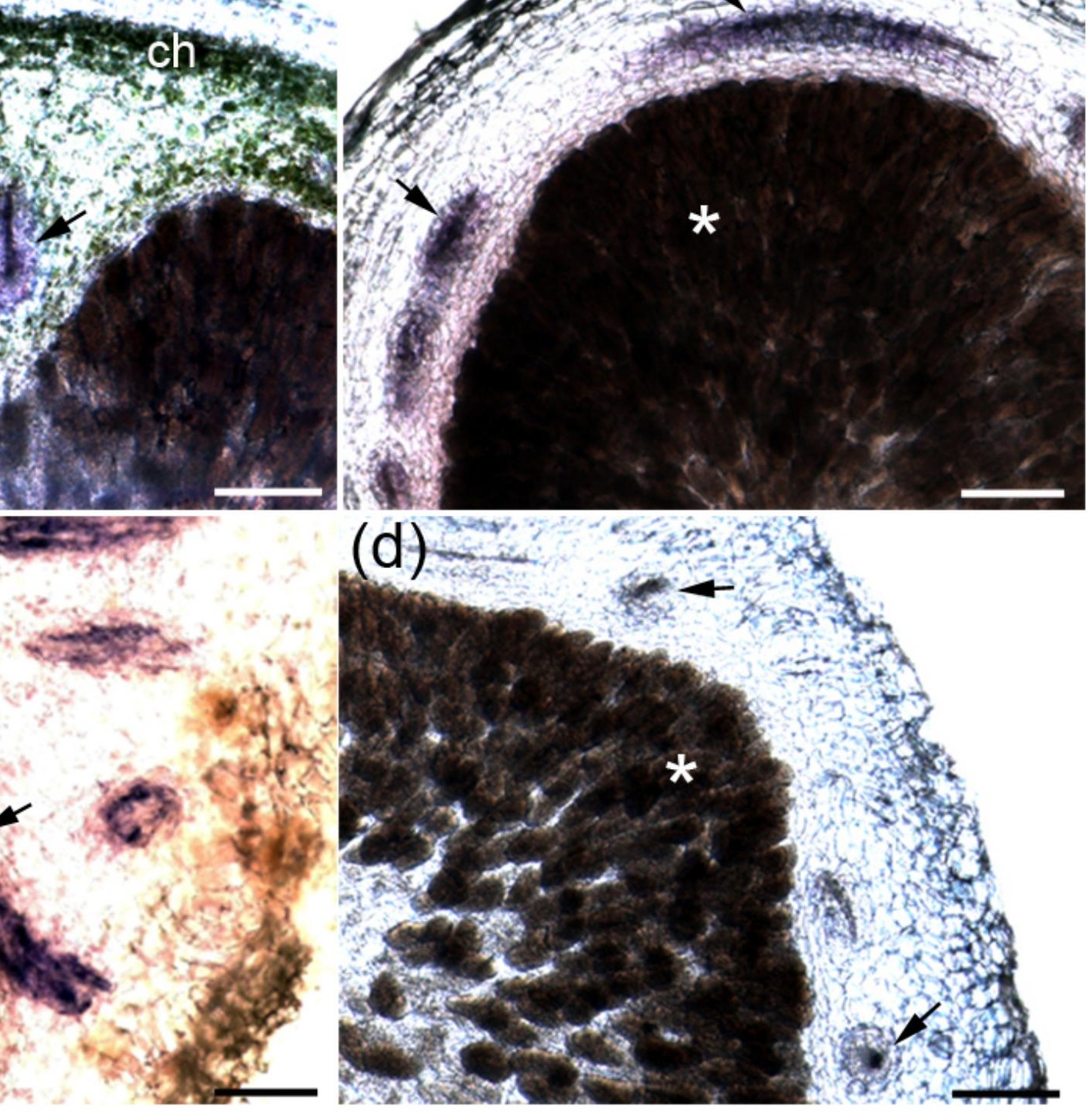

$2 \frac{2}{2}$

(a)

(h)

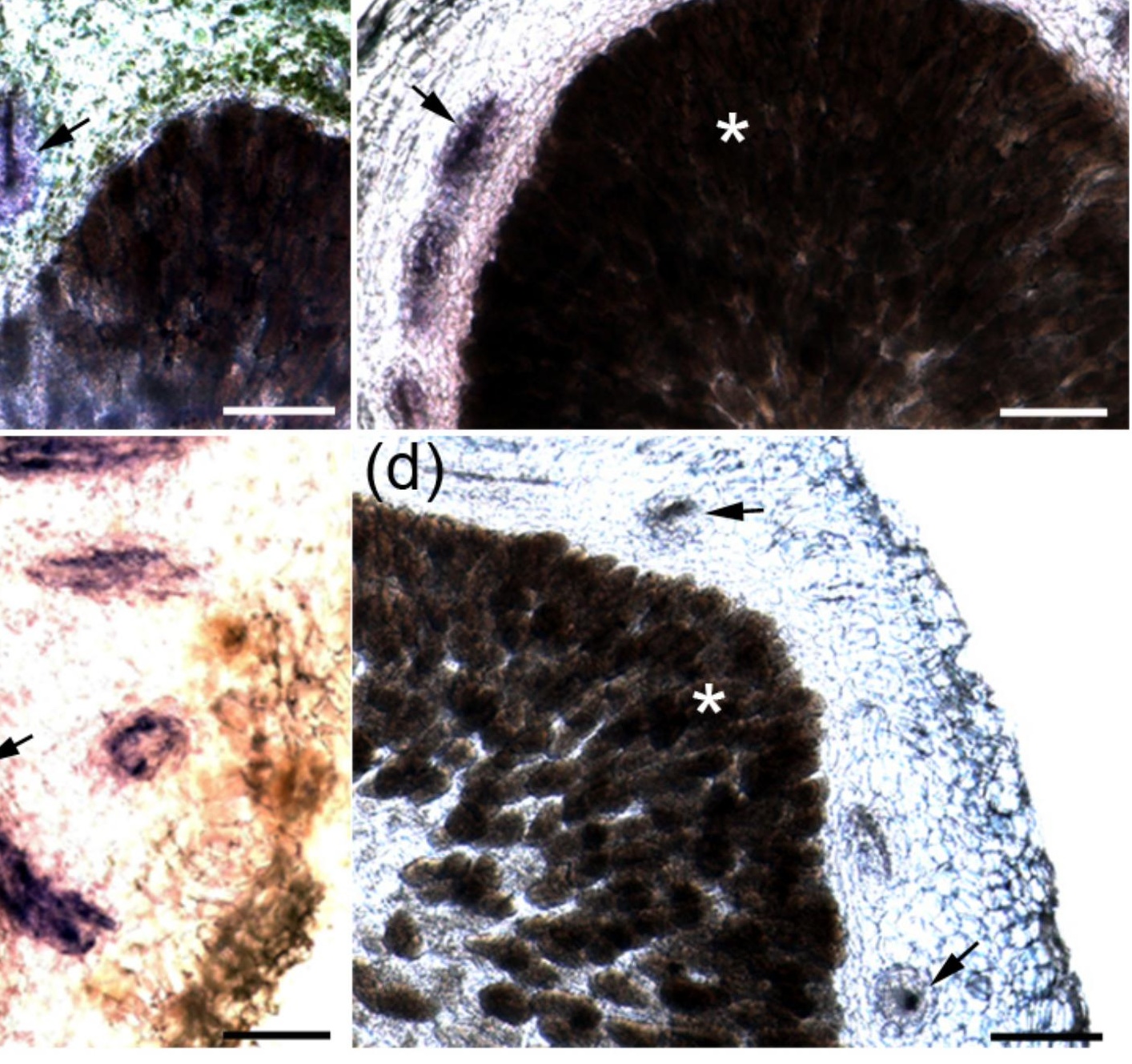


Table S1 Relative abundance of CuZnSODc protein in stem and root nodules of Sesbania rostrata

Number of gold particles on organelles in cells from high-pressure frozen stem and root nodules after immunogold labeling with an antibody against CuZnSODc. Gold particles in sections with nonimmune serum for all three types of cells examined were $<2.5$ in the cytoplasm, nuclei, vacuoles and other cellular compartments. Values are means \pm SE of 10 measurements, each corresponding to a different cell. n/a, not applicable.

\begin{tabular}{lcccc}
\hline \multicolumn{1}{c}{ Cell type } & Cytoplasm & Nuclei & Vacuoles & $\begin{array}{c}\text { Mitochondria and } \\
\text { other organelles }\end{array}$ \\
\hline Infected cells & $21 \pm 8$ & $482 \pm 27$ & $\mathrm{n} / \mathrm{a}$ & $8 \pm 3$ \\
Cortical cells & $10 \pm 3$ & $447 \pm 29$ & $19 \pm 4$ & $13 \pm 4$ \\
Vascular bundle cells & $7 \pm 2$ & $395 \pm 39$ & $\mathrm{n} / \mathrm{a}$ & $10 \pm 6$ \\
\hline
\end{tabular}

